Columbia Law School

Scholarship Archive

1975

\title{
Constitutional Regulation of Provisional Creditor Remedies: The Cost of Procedural Due Process
}

Robert E. Scott

Columbia Law School, rscott@law.columbia.edu

Follow this and additional works at: https://scholarship.law.columbia.edu/faculty_scholarship

Part of the Constitutional Law Commons, and the Law and Economics Commons

\section{Recommended Citation}

Robert E. Scott, Constitutional Regulation of Provisional Creditor Remedies: The Cost of Procedural Due Process, 61 VA. L. ReV. 807 (1975).

Available at: https://scholarship.law.columbia.edu/faculty_scholarship/312

This Article is brought to you for free and open access by the Faculty Publications at Scholarship Archive. It has been accepted for inclusion in Faculty Scholarship by an authorized administrator of Scholarship Archive. For more information, please contact scholarshiparchive@law.columbia.edu. 


\title{
CONSTITUTIONAL REGULATION OF PROVISIONAL CREDITOR REMEDIES: THE COST OF PROCEDURAL DUE PROCESS
}

\author{
Robert E. Scott*
}

In recent years a series of Supreme Court decisions ${ }^{1}$ has purported to envelop the rights of defaulting debtors in an enlarged concept of procedural due process. The central theme underlying this development is clearly an attempt by the Court to impose some degree of constitutional control on the exercise of provisional creditor remedies. ${ }^{2}$ The path that leads from Sniadach v. Family Finance Corp. ${ }^{3}$

* Professor of Law, University of Virginia School of Law. I wish to thank Jerry Mashaw and Warren Schwartz of the University of Virginia School of Law for valuable comments and suggestions on earlier versions of this article. Any errors that renuain are, of course, my sole responsibility.

' Sniadach v. Family Finance Corp., 395 U.S. 337 (1969); Swarb v. Lennox, 405 U.S. 166 (1972); D. H. Overnieyer Co. v. Frick Co., 405 U.S. 174 (1972); Fuentes v. Shevin, 407 U.S. 67 (1972); Mitchell v. W. T. Grant Co., 416 U.S. 600 (1974); Nortb Georgia Finisbing, Inc. v. Di-Chem, Inc., 419 U.S. 601 (1975).

In addition to these cases bearing directly on the due process rights of the defaulting debtor, the Supreme Court has, in a series of related decisions, enunciated the scope of due process protection accorded property interests in general. Arnett v. Kennedy, 416 U.S. 134 (1974); Lynch v. Household Finance Corp., 405 U.S. 538 (1972); Bell v. Burson, 402 U.S. 535 (1971); Boddie v. Connecticut, 401 U.S. 371 (1971); Goldberg v. Kelly, 397 U.S. 254 (1970).

2395 U.S. 337 (1969). In Sniadach, the Court held tbat, in the absence of a special state or creditor interest, due process requires that a debtor be given notice and an opportunity to be heard prior to a pre-judgment garnishment of his wages.

3 The phrase "provisional creditor remedy" covers a range of pre-judgment statutory remedies. The cominon thrust of all these procedures, however, is to permit a seizure of a debtor's assets pending adjudication of an underlying clain. The principal remedies that have been subjected to constitutional attack fall into two main categories: 1) pre-judgment attachnient or garnishment statutes permitting a seizure of the debtor's property by an unsecured creditor either to secure jurisdiction or to prevent sequestration or removal of the debtor or his assets prior to ultimate adjudication; 2) pre-judginent replevin statutes permitting a secured creditor to repossess assets subject to a prior security interest upon allegations of default and insecurity.

In addition, most states have statutory provisions granting possessory liens to landlords, innkeepers, repairmen, and warehousemen which permit them to retain goods in their custody pending paynent for services rendered. These statutes have also been subject to due process attack where they authorize an ex parte seizure by the creditor. See generally Clark \& Landers, Sniadach, Fuentes and Beyond: The Creditor Meets the Constitution, 59 VA. L. REv. 355, 383-403 (1973). The issue of state involvement in the action of the creditor has largely determined whether additional due process controls must be imposed on these various possessory liens. 
to North Georgia Finishing, Inc. v. Di-Chem, Inc. ${ }^{4}$ is however, far from clear and the cases have provoked serious questioning of the meaning and impact of this doctrine. ${ }^{5}$ Due process as reflected in

In those cases where state officials have been directly involved in the enforcement of the challenged lien, the statutes have been found constitutionnally defective. See, e.g., Mason v. Garris, 360 F. Supp. 420 (N.D. Ga.), modified, 364 F. Supp. 452 (N.D. Ga. 1973) (enforcement of lien required application to the state courts); Santiago v. McElroy, 319 F. Supp. 284 (E.D. $\mathrm{Pa}$. 1970) (state officers seized debtor's assets pursuant to distress for rent procedures); Adams v. Dept. of Motor Vehicles, 113 Cal. Rptr. 145, 11 Cal. 3d 146, 520 P.2d 961 (Sup. Ct. Cal. 1974) (enforcement of the lien supervised by state agency).

Even where no state officer has been involved in the enforcement of the lien, courts considering cases involving innkeeper's and landlord's liens have generally found the requisite state action. See, e.g., Hall v. Garson, 468 F.2d 845 (5th Cir. 1972), 430 F.2d 430 (5th Cir. 1970) (landlord's lien); McQueen v. Lambert, 348 F. Supp. 1334 (M.D. Fla. 1972) (landlord's lien); Dielen v. Levine, 344 F. Supp. 823 (D. Neb. 1972) (landlord's lien); Collins v. Viceroy Hotel Corp., 338 F. Supp. 390 (N.D. Ill. 1972); Klim v. Jones, 315 F. Supp. 109 (N.D. Cal. 1970) (innkeeper's lien); Ble v. Globe-Wernicke Realty Co., 33 N.Y.2d 15, 300 N.E.2d 710 (1973) (innkeeper's lien). But see McGuane v. Chenango Court, Inc., 431 F.2d 1189 (2d Cir. 1970), cert. denied, 401 U.S. 994 (1971); Kerrigan v. Boucher, 326 F. Supp. 647 (D. Conn.), aff'd 450 F.2d 487 (2d Cir. 1971).

Although some courts have also found state action in the exercise of a repairman's lien, Cockerel v. Caldwell, 378 F. Supp. 491 (W.D. Ky. 1974); Lee v. Cooper, C.A. No. 74-104 (D.N.J. 1974); Ford v. Dean's O.K. Tire Store, Inc., Civ. No. L.V. (D. Nev. 1974); it has been held that these statutes are indistinguishable from self-help repossession under UCC $\$ 9-503$, where the overwhelming majority of courts have found no state action in a private repossession pursuant to a statutory scheme. Parks v. "Mr. Ford," 386 F. Supp. 1251 (E.D. Pa. 1975). See cases cited note 19 infra.

1419 U.S. 601 (1975). Di-Chem invalidated the Georgia pre-judgment garnishment statute as violating procedural due process. This decision was preceded by Fuentes v. Shevin, 407 U.S. 67 (1972), which, relying on the Sniadach rationale, extended due process protection to preclude pre-hearing seizure of goods by a creditor pursuant to a statutory replevin action, and by Mitchell v. W.T. Grant Co., 416 U.S. 600 (1974), in which the Court sharply limited the effect of Fuentes by finding in the Louisiana ex parte sequestration procedure adequate safeguards to satisfy due process. The Georgia statute in Di-Chem, however, was found to meet neither of these standards.

${ }^{5}$ See generally Clark \& Landers, Sniadach, Fuentes and Beyond: The Creditor Meets the Constitution, 59 VA. L. Rev. 355 (1973); Gardner, Fuentes v. Shevin: The New York Creditor and Replevin, 22 Bufralo L. Rev. 17 (1972); Krahıner, Clifford \& Lasley, Fuentes v. Shevin: Due Process and the Consumer, A Legal and Empirical Study, 4 Texas TEch L. Rev, 23 (1972). The series of cases froin Sniadach to $\mathrm{Di}$-Chem has clearly not resolved the basic question of what satisfies procedural due process in the exercise of the traditional remedies under attack-pre-judgment attachment, garnishment, and replevin.

It appears that the issues raised in the previous decisions will be considered once more by the Supreme Court. The Court has recently agreed to review Curtis Circulation Co. v. Sugar, No. 74-859, 43 U.S.L.W. 3545 (April 15, 1975), in which a New York district court held that the New York pre-judgment attachment statute violated due process in permitting the $e x$ parte seizure of a commercial defendant's assets upon the creditor's allegations of 1) fraud in incurring the liability and 2) assignment or removal of the property with the intent to defraud creditors. The district court found that the New York statute did not provide sufficient controls on the ex parte process to meet the standards of the Louisiana statute sustained in Mitchell. Sugar v. Curtis Circulation Co., 383 F. Supp. 643 (1974). For a further discussion of the Sugar case see notes 138, 199 infra. 
Sniadach and Fuentes $v$. Shevin, ${ }^{6}$ initially imposed on state enforcement procedures, in the absence of a compelling state or creditor interest, the requirement that the defaulting debtor be granted adequate notice and an opportunity to be heard before he could be deprived, even temporarily, of any significant property interest. ${ }^{7}$ Subsequent interpretations in Mitchell v. W. T. Grant Co. ${ }^{8}$ and DiChem recognized that an ex parte deprivation of the debtor's property interest could be sustained where the enforcement process incorporated various controls, including specific factual allegations of entitlement by the creditor, review of the request for ex parte process by a judicial officer, and an opportunity for the debtor to challenge the deprivation at an "immediate" post-seizure hearing. ${ }^{9}$ Any attempt, however, to search beyond this familiar litany for the impact of this doctrine on the debtor-creditor relationship and the state dispute resolution mechanism, quickly reveals that there is no consistent understanding of what procedural due process requires, when it is satisfied, and what if any purpose it serves.

Few would question the need to reexamine the concept of procedural due process in the context of the defaulting debtor. This article will undertake such a reexamination from the perspective of economic theory with particular focus on the enforcement costs of due process. A recognition of the utility of applying economic analysis to legal problems requires as well a recognition of its limitations. ${ }^{10}$ These limitations are particularly acute in an analysis of constitutional principle ${ }^{11}$ and of the individual's relationship to the state, and indeed in any case where fundamental social values must be measured..$^{12}$ Economic analysis does provide, however, a method

6 407 U.S. 67 (1972).

7 See generally Fuentes v. Shevin, 407 U.S. 67, 78, 80, 83-84 (1972).

8416 U.S. 600 (1974).

- See generally North Georgia Finishing, Inc. v. Di-Chem, Inc., 419 U.S. 601, 606-07 (1975).

10 See Buchanan, Good Economics-Bad Law, 60 VA. L. Rev. 483 (1974); Leff, Economic Analysis of Law: Some Realism About Nominalism, 60 VA. L. Rev. 451 (1974); Polinsky, Economic Analysis as a Potentially Defective Product: A Buyer's Guide to Posner's 'Economic Analysis of Law,' 87 HaRv. L. Rev. 1655 (1974).

" For a discussion of the distinction hetween principles and policy in constitutional adjudication, and the impact of the distinction on the scope of judicial review, see Wellington, Common Law Rules and Constitutional Double Standards; Some Notes on Adjudication, 83 YALE L.J. 221, 265-311 (1973).

12 See, e.g., Leff, supra note 10 , at 466 . Leff argues that efficiency analysis is itself normative and, therefore, is limited by its own assumptions concerning human behavior. As an example, he argues that one cannot criticize a trial-type hearing as being inefficient because 
of evaluating the effectiveness of the procedures used to implement due process. This method seems particularly appropriate since a cost-benefit equation has emerged as the Court's primary evaluative tool in reviewing specific procedural requirements. A cost analysis of legal procedure initially assumes that a fundamental goal of procedure is to produce an accurate resolution of disputes. In the particular context of debtor default, due process, to the extent that it requires additional procedures in ex parte situations, imposes significant "direct" or litigation costs on the enforcement process. ${ }^{13}$ These costs justify themselves in economic terms only if they contribute to at least a corresponding reduction in "error" costs-social costs that arise when the legal system fails to perform accurately its assigned function of dispute resolution. ${ }^{14}$ The goal of allocative efficiency is to minimize the sum of these costs.

This analysis of procedural due process requirements, while framed in terms of cost theory, is consistent with the explicit recognition by the Supreme Court that due process requirements validly imposed on one equation of interests may not be justifiable when applied to an alternate equation. ${ }^{15}$ If this basic understanding is

it does not significantly reduce the risk of an erroneous resolution unless one is willing to assume that the reduction of error is a controlling purpose of the procedures. These same procedures may be perfectly justifiable if "[t]he social purpose of trial-type hearings [has] little to do with eliminating error. . . . It may be pure theatre for the participants, or an alternative to ulcers, (or a way of producing them in others). . . . You can't know that a thing is not being done well until you know what it is that is being done." Id. at 466.

${ }_{13}$ Such costs would include opportunity costs of the parties, lawyer, litigant and court time, etc. The cost analysis contained in this article, including the designation of the factors comprising the cost of enforcement, is derived principally from Professor Posner's definitive analysis of the costs mherent in legal dispute resolution. Posner, An Economic Approach to Legal Procedure and Judicial Administration, 2 J. LEGAL StudIes, 399, 400-02 (1973).

14 Id. at 401 . Error can be caused by a failure to sustain a valid claim as well as by imposing liability based on an erroneous or "false" claim. Error costs are themselves a product of two factors: (1) the incidence of error (the probability that the legal dispute resolution mechanism will not achieve a correct result); and (2) the impact of error (the costs imposed on the losing party due to the erroneous result).

is See generally Arnett v. Kennedy, 416 U.S. 134, 154-58, 167-70 (1974) (Powell, J., concurrimg).

Justice Rehnquist, writing the majority opinion in Arnett, expressed the variable nature of procedural due process requirements by concluding:

The types of "liberty" and "property" protected by the Due Process Clause vary widely, and what may be required under that clause in dealing witl one set of interests Id. at 155 .

which it protects may not be required in dealing with another set of interests.

The recognition that the standards of due process are measured in terms of the equation of interests presented in a given case may produce results that seem anomalous. A recent 
applied to limitations on the use of provisional creditor remedies, the central question is whether the procedures perform their intended function. A cost evaluation of due process in this context is necessary because the doctrine as developed appears to bear little relationship to its originating purposes. It can be persuasively argued that the initial concept reflected in Sniadach embodied constitutional control of creditor remedies in circumstances where the debtor had been deprived of his expectation of just treatment because of a systemic imbalance permitting creditor overreaching. ${ }^{16}$ The use of provisional creditor remedies where the transaction arose out of this imbalance in the market was implicitly viewed as denying the debtor fundamental faimess. ${ }^{17}$ The Court intended, through due process control, to preclude most creditors in a dominant market position from using the particular remedy of pre-judgment wage garnishment. ${ }^{18}$ But using procedural due process to curtail the exercise of provisional creditor remedies creates difficulties when the procedural arrangements upon default are, either explicitly or implicitly, subject to agreement between the parties. ${ }^{19}$ Therefore, if

example is Gerstein v. Pugh, 419 U.S. 815 (1975), in which the Court in dictum asserted that due process did not require a judicial hearing prior to detention pursuant to a prosecution by information. Id. at 865 . In his concurring opinion, Mr. Justice Stewart recognized the anomaly:

Specifically, I see no need in this case for the Court to say that the Constitution extends less procedural protection to an imprisoned human being than is required to test the propriety of gamisheeing a commercial bank account . . . [or] the custody of a refrigerator...

Id. at 869-70.

18 See Sniadach v. Family Finance Corp., 395 U.S. 337, 340-42 (1969).

"Id.

18 See notes $36-37$ infra and accompanying text.

10 An excellent illustration of the problems underlying constitutional control of the consensual relationship between debtor and creditor can be found in the debate over the extension of procedural due process to self-help repossession under UCC $\$ 9-503$. Although the debate has centered on whether the exercise of the creditor remedy could be attributed to the state to satisfy the state action requirement of the fourteenth amendment, the underlying issue has been the degree to which an agreed-upon procedural remedy upon default can be subjected to constitutional control without seriously disturbing the allocation of rights and duties upon default. See, e.g., Mentschikoff, Peaceful Repossession Under the Uniform Commercial Code: A Constitutional and Economic Analysis, 14 WM. \& MARY L. REv. 767 (1973). Althougb several district courts have found the requisite state action, Boland v. Essex County Bank and Trust Co., 361 F. Supp. 917 (D. Mass. 1973); Gibbs v. Titleman, 369 F. Supp. 38 (E.D. Pa. 1973), rev'd 502 F.2d 1107 (3d Cir. 1974); Adams v. Egley, 338 F. Supp. 614 (S.D. Cal. 1972), rev'd sub nom. Adams v. Southern California First Nat'l Bank, 492 F.2d 324 (9th Cir. 1973), cert. denied, 419 U.S. 1006 (1974), the majority of courts ruling on the constitutionality of Section 9-503 have found private conduct not to be under color of state law. See, e.g., Turner v. Impala Motors, 503 F.2d 607 (6th Cir. 1974); Gibbs v. Titleman, 502 F.2d 1107 (3d 
constitutional control is to increase significantly the protection afforded the debtor's interest, the bargaining process that has produced apparent assent to the procedural actions of the creditor upon default must be examined. Sniadach and Fuentes implicitly reflect this substantive concept of "constitutional unconscionability." In Di-Chem, however, the Supreme Court explicitly declined to embrace the concept of substantive control while retaining the procedural requirements identifled in the earlier decisions..$^{20}$ Once procedural due process limitations are imposed independently of any control on the debtor-creditor relationship, the benefit of these procedures in reducing the social costs of erroneous deprivations becomes a crucial question.

This article attempts to establish that, because of the substantive problems imphicit in the debtor-creditor relationship and the context of default, the post-Sniadach doctrine of procedural due process-whether given the broad interpretation reflected in Fuentes or the narrow view of Mitchell-does not significantly increase accuracy or protection of the debtor's interest. Part I of the article reviews the doctrine as it has developed in the context of provisional creditor remedies. This development seems to have produced a recognition by the Court that procedural due process does not encompass a rigid procedural standard to be superimposed on provisional creditor remedies generally. Rather, the Court has concluded that due process should be defined only after any additional procedures inposed demonstrate their potential benefit in reducing the costs of erroneous deprivation. This development has been characterized by a shift in focus from constitutional control of creditor behavior to a constitutional supervision of state dispute resolution inechanisins. Once this shift in einphasis is recognized, the resolution in Di-Chem illustrates the problem of constitutional control.

Cir. 1974), rev'g 369 F. Supp. 38 (E.D. Pa. 1973); Nichols v. Tower Grover Bank, 497 F.2d 404 (8th Cir. 1974); James v. Pinnix, 495 F.2d 206 (5th Cir. 1974); Shirley v. State Nat'l Bank of Connecticut, 493 F.2d 739 (2d Cir. 1974); Adams v. Southern California First Nat'l Bank, 492 F.2d 324 (9th Cir. 1973), rev'g Adams v. Egley, 338 F. Supp. 614 (S.D. Cal. 1972), cert. denied, 419 U.S. 1006 (1974); Bichel Optical Lab., Inc. v. Marquette Nat'l Bank, 487 F.2d 906 (8th Cir. 1973); Oller v. Bank of America, 342 F. Supp. 21 (N.D. Cal. 1972); Greene v. First Nat'l Exchange Bank, 348 F. Supp. 672 (W.D. Va. 1972); McCormick v. First Nat'l Bank, 322 F. Supp. 604 (S.D. Fla. 1971); Messenger v. Sandy Motors, Inc., 121 N.J. Super. 1, 295 A.2d 402 (1972).

20 419 U.S. at 608. 
The Court's failure to identify explicitly the factors that determine appropriate procedural standards is understandable because these factors can be altered both by the agreement between the parties and the market relationships that produced the agreement. A possible explanation for the absence of a clear articulation of the requirements of due process is that the Court, unwilling to undertake substantive regulation of the bargaining process, is no longer certain that the procedural mechanism can be adjusted more accurately by constitutional adjudication than by legislative delineation of the state enforcement process.

In order to support the proposition that the default enforcement process is not readily susceptible to specific constitutional control, Part II of the article assesses the enforcement costs of the various procedural requirements identified by the Court as constitutionally relevant. Because of the consensual nature of the debtor-creditor relationship and the peculiar context of default, these requirements, if generally imposed, may well be less justifiable in terms of the assumed goals of legal procedure than available procedural alternatives that are equally identifiable. An accurate determination of the impact of specific procedures requires a complex analysis based on reliable assumptions about the context of a particular dispute. Unless the Court is prepared, therefore, to undertake a continuous supervision of the debtor-creditor relationship, the state enforcement process should not be closely circumscribed by procedural requirements of questionable utility.

\section{A Procedural Due Process Primer-The Doctrine Unfolds}

\section{A. Sniadach and Its Progeny Revisisted}

Before 1969, the Supreme Court viewed procedural due process as requiring "where only property rights are concerned, that there be at some stage an opportunity for a hearing and judicial determination." ${ }^{21}$ Consequently, the traditional provisional creditor remedies of pre-judgment attachment and garnishment and statutory replevin mvolved initial ex parte action by the creditor even though a temporary deprivation of a debtor's property rights resulted pending judicial resolution of the underlying claim. ${ }^{22}$ This traditional

${ }^{21}$ Ewing v. Mytinger \& Casselberry, Inc. 339 U.S. 594, 599 (1950).

2 See generally McKay v. McInnes, 279 U.S. 820 (1929); Coffin Bros. v. Bennett, 277 U.S. 29 (1928); Ownbey v. Morgan, 256 U.S. 94 (1921). 
understanding of the interplay between due process and the deprivation of property rights was an effort to balance the state's interest in providing machinery by which creditors could quickly and decisively collect their debts ${ }^{23}$ against the debtor's interest in preventing a wrongful depreviation of his property rights.

The status of provisional creditor remedies was jarred considerably when the Supreme Court, in Sniadach v. Family Finance Corp. ${ }^{24}$ invalidated a Wisconsin pre-judgment garnishment statute that authorized ex parte seizure of the wages of an allegedly defaulting debtor. ${ }^{25}$ The creditor had initiated garnishment proceedings against the debtor and her employer as garnishee based on an ex parte allegation of a $\$ 420$ indebtedness on a promissory note. The garnishee-employer adınitted indebtedness to the debtor for one week's wages and withheld, pursuant to statute, one-half of the wages pending court determination of the validity of the claim. ${ }^{20}$

The Court held that this "interim freezing of wages" without prior notice and an opportunity to be heard violated procedural due process. Mr. Justice Douglas, writing for the majority, indicated that provisional creditor remedies might well meet the requirements of

${ }^{23}$ The balancing approach to procedural due process is reflected in a number of preSniadach Supreme Court decisions. See generally Ewing v. Mytinger \& Casselberry, Inc., 339 U.S. 594 (1950); Fahey v. Mallonee, 332 U.S. 245 (1947); Coffin Bros. Co. v. Bennett, 277 U.S. 29 (1928).

Under this analysis, due process was viewed as requiring a consideration of "[ $t$ ]he precise nature of the interest that has been adversely affected, the manner in which this was done, the reasons for doing it, the available alternatives to the procedure that was followed . . . the balance of hurt complained of and good accomplished." Joint Anti-Fascist Comm. v. McGrath, 341 U.S. 123, 163 (1951) (Frankfurter, J., concurring).

This basic conception of due process has been widely followed by the courts. See, e.g., Wasson v. Trowbridge, 382 F.2d 807 (2d Cir. 1967), where the court said:

[T]o deterinine in any given case what procedures due process requires, the court inust carefully determine and balance the nature of the private interest affected and of the government interest involved ....

Id. at 811.

24395 U.S. 337 (1969).

25 Wis. Stat. AnN. $\$ 267.01-.24$ (Supp. 1969). At the time of the action there were 16 states with similar statutory schemes. 1 CCH PoverTy LAw REP. ๆ 129.751 (1972).

${ }^{26}$ The Wisconsin statute permitted the creditor to initiate garnishment proceedings against any person in possession of his debtor's property. Wis. STaT. ANN. $\$ 267.01$ (Supp. 1969). The statute then required the garnishee-employer to pay over to the debtor a subsistence allowance up to $50 \%$ of the wages owing and to retain the remaining property of the debtor until final adjudication of the claim. Id. $\$ \S 267.04,267.18(2)$ (a) (Supp. 1969).

In Sniadach, the debtor received notice of the seizure the same day tbat process was issued; the statute, however, only required notiflcation of the debtor within 10 days of the garnishment. Id. § 267.07 (Supp. 1969). 
due process in extraordinary situations. ${ }^{27}$ But in the absence of a special state or creditor interest and a narrowly drawn statute, this process was unacceptable as applied to wages, " $a$ specialized type of property presenting distinct problems in our economic system." 28 Douglas' opinion clearly expressed prinary concern over the action undertaken by the creditor: "a procedural rule that may satisfy due process for [provisional remedies] in general" may not give

${ }^{27} 395$ U.S. at 339 . The recognition that summary process might he constitutionally permissible in certain situations permitted the Court to reconcile previous decisions validating prejudgment deprivations pending judicial adjudication of the controversy. Cafeteria \& Restaurant Workers, Local 473 v. McElroy, 367 U.S. 886 (1961); Zittinan v. McGrath, 341 U.S. 446 (1951); Ewing v. Mytinger \& Casselberry, Inc., 339 U.S. 594 (1950); Standard Oil Co. v. Superior Court, 44 Del. 538, 62 A.2d 454 (1948), appeal dismissed for want of substantial federal question, 336 U.S. 930 (1949); Fahey v. Mallonee, 332 U.S. 245 (1947); Huron Holding Corp. v. Lincoln Mine Operating Co., 312 U.S. 183 (1941); Rorick v. Devon Syndicate, Ltd., 307 U.S. 299 (1939); Sanders v. Armour Fertilizer Works, 292 U.S. 190 (1934); Phillips v. Comm'r, 283 U.S. 589 (1931); McKay v. McInnes, 279 U.S. 820 (1929); Ownbey v. Morgan, 256 U.S. 94 (1921); Clark v. Wells, 203 U.S. 164 (1906); Harris v. Balk, 198 U.S. 215 (1905); Rothschild v. Knight, 184 U.S. 334 (1902); King v. Cross, 175 U.S. 396 (1899); Chicago, R.I. \& Pac. Ry. v. Sturm, 174 U.S. 710 (1899); Springer v. United States, 102 U.S. 586 (1880); Pennoyer v. Neff, 95 U.S. 714 (1877); Cooper v. Reynolds, 77 U.S. (10 Wall.) 308 (1870); Brashear v. West, 32 U.S. (7 Pet.) 608, 617-24 (1833).

Three cases cited by the Court as illustrating "extraordinary situations" would seen to limit a pre-hearing seizure of property to cases requirmg the protection of a compelling governmental interest. Fahey v. Mallonee, 332 U.S. 245 (1947) (federal statute authorizing summary seizure of the assets of a savings and loan association where the operation threatened the interests of creditors, depositors, and the public); Ewing v. Mytinger \& Casselberry, Inc., 339 U.S. 594 (1950) (authorized seizure by a federal Food \& Drug administrator of "misbranded articles" that were believed dangerous to health, fraudulently mislabeled, or materially unisleading); Coffin Bros. Co. v. Bennett, 277 U.S. 29 (1928) (state statute authorizing state Banking Superintendent to attach failed bank stockholders' property where an assessment of $100 \%$ stockholder liability had been made in order to uphold public confidence in the banking system).

In addition, however, the Court cited Ownbey v. Morgan, 256 U.S. 94 (1921), as an additional illustration of an extraordinary situation sufficient to sanction pre-judgment ex parte process. In Ownbey the Court sustained a state statute permitting a court to deny a nonresident debtor in an attachment proceeding the right to appear unless he posted bond equal to the value of the attached property. The holding primarily recognized the creditor's interest in obtaining security for the satisfaction of debts owed by non-resident debtors. The reference to Ownbey implicitly recognized that the creditor's imterest in collecting debts when ordinary process was not available or satisfactory could well outweigh the debtor's interest in preventing a temporary deprivation of property rights.

Lower courts following Sniadach generally interpreted this exception as permitting sum. mary seizure of the assets of a non-resident debtor as a basis for quasi-in-rem jurisdiction even where alternative bases of jurisdiction might have been available. See, e.g., Lebowitz v. Forbes Leasing \& Fin. Corp., 456 F.2d 979, 982 (3d Cir. 1972); Tucker v. Burton, 319 F. Supp. 567, 569 (D.D.C. 1970). The use of summary seizure to secure jurisdiction appears, however, to have been more carefully circumscribed by Fuentes. See note 53 infra.

$2 s 395$ U.S. at 340 (emphasis added). 
"necessary protection to all property in its modern forms." ${ }_{29} \mathrm{He}$ perceived the wage garnishment mechanism as providing the creditor with extraordinary leverage, which might be used to "drive a wage-earner to the wall," an invalid claim merely to secure the return of his wages. ${ }^{31}$

Douglas' opinion had substantive due process implications: arguably it represented the beginnings of an extension of constitutional protections to individuals, not on the basis of the property interest invoked, ${ }^{32}$ but rather on the basis of their economic status. While labeling due process "substantive" or "procedural" often does not increase analytical precision, ${ }^{33}$ constitutional protection of the consumer debtor, who has a significantly inferior status in his relationship with the professional creditor, must be distinguished functionally from the traditional notion of procedural fairness in the enforcement process. The substantive implications of Douglas' opinion were somewhat obscured by Justice Harlan's concurrence, which focused not on the unfairness implicit in pre-judgment garnishment of wages but rather on the deprivation of the use of the debtor's wages during the period between garnishment and judicial resolution of the underlying claim. ${ }^{34}$

The presence of a new kind of substantive protection in procedural due process clothing created understandable confusion as to

2395 U.S. at 340 .

so Id. at $341-42$.

31 Id. at 341. There is substantial evidence that wage garnishment is used by creditors less as a collection dervice than as a way to exert leverage, prompting the debtor either to refinance the obligation or pay tbe debt. See Note, Wage Garnishment in Washington-An Empirical Study, 43 Wash. L. Rev. 743 (1968); Note, Wage Garnishment as a Collection Device, 1967 Wis. L. REv. 759.

32 Graham, Poverty and Substantive Due Process, 12 ArIz. L. Rev. 1 (1970); Note, The Growth of Procedural Due Process Into a New Substance: An Expanding Protection for Personal Liberty and a "Specialized Type of Property". . . In Our Economic System, 66 Nw. U. L. Rev. 502 (1971). See also Sniadach v. Family Finance Corp., 395 U.S. at 344 (Black, J., dissenting).

33 The term "suhstantive due process" is generally used to designate the "economic due process" cases in which the Supreme Court invalidated state and federal attempts at social legislation as "impairments of freedom of contract." See, e.g., Allgeyer v. Louisiana, 165 U.S. 578 (1897); Lochner v. New York, 198 U.S. 45 (1905); Adair v. United States, 208 U.S. 161 (1908); Coppage v. Kansas, 236 U.S. 1 (1915); Adams v. Tanner, 244 U.S. 590 (1917); Adkins v. Children's Hospital, 261 U.S. 525 (1923); Tyson \& Bro. v. Banton, 273 U.S. 418 (1927); Ribnik v. McBride, 277 U.S. 350 (1928); Williams v. Standard Oil Co., 278 U.S. 235 (1929); New State Ice Co. v. Liebmann, 285 U.S. 262 (1932); Morehead v. New York ex rel Tipaldo, 298 U.S. 587 (1936).

34395 U.S. at 342 (Harlan, J., concurring). 
the appropriate scope of the emerging doctrine. Some courts interpreted Sniadach to require notice and hearing prior to any deprivation of significant property rights, ${ }^{35}$ while others isolated wages from other kinds of property as deserving extraordinary procedural protection. ${ }^{36}$ Ignored in the process was the possibility that the ultimate thrust of the decision was not to provide increased procedural protection for a special type of property, but rather was to limit creditor use of the enforcement process where the imbalance in the debtorcreditor relationship permitted "unconscionable" overreaching. By imposing additional procedures on a remedy designed to permit quick and decisive creditor action the effectiveness of the remedy for the creditor would be largely destroyed; the provisional remedy would then be indistinguishable from the ordinary process of reducing the claim to judgment and initiating post-judgment garnishment proceedings. The effect of the additional procedural requirements would be judicial abolition of pre-judgment wage garnishment. Admitting the validity of the Court's concern with the abusive potential of pre-judgment wage garnishment, was imposing these additional procedures on a remedy used to resolve disputes arising out of consensual transactions an appropriate respose?

If the perspective is shifted from the invalidation of existing statutes to the incorporation of the new constitutional requirements into an existing statutory scheme of creditor remedies, the problems posed by Sniadach become more apparent. On the one hand, the doctrine could be viewed as requiring merely that, prior to any state-sanctioned deprivation, the debtor be notified of his opportunity to participate in an adjudicatory hearing on the probable validity of the underlying claim. Since most debtors do not appear to answer claims of default, ${ }^{37}$ creditors could in many cases effect the deprivation without any adjudication of the dispute. It would seem

${ }_{35}$ See, e.g., Randone v. Appellate Dept., 5 Cal. 3d 536, 488 P.2d 13, 96 Cal. Rptr. 709 (1971) (attachment of bank account); Larson v. Fetherston, 44 Wis. 2d 712, 172 N.W.2d 20 (1969) (pre-judgment garnishment of accounts receivable).

3s See, e.g., People ex rel. Lynch v, Superior Court, 1 Cal. 3d 910, 464 P.2d 126, 83 Cal. Rptr. 670 (1970) (general attachment of property; refusal to render an advisory opinion); Termplan, Inc. v. Superior Court, 105 Ariz. 270, 463 P.2d 68 (1969) (general attachment of property); Johnston v. Cunningham, 12 Cal. App. 3d 123, 90 Cal. Rptr. 487 (1970) (attachment of a dehtor's prune crop).

${ }^{37}$ In an empirical study of defaulting debtors in four major urban centers, Professor Caplovitz found that between $64 \%$ (Chicago) and $96 \%$ (New York) of the debtors surveyed failed to answer their summons, while over $90 \%$ of the cases in all cities surveyed termmated in default judgments. 2 D. Caplovitz, Debtors in Default 11-35, 11-66 (1971). 
that if a default judgment were the end product of creditor action, this interpretation of Sniadach would not produce a meaningful increase in accuracy or protection of the debtor's interest.

On the other hand, Sniadach could be interpreted as requiring a pre-seizure hearing unless the debtor knowingly and intelligently waived the hearing. Here the costs of the procedure would be significantly increased: Notice would have to be made meaningful to the debtor, ${ }^{38}$ a method would have to be devised to ensure the debtor's participation at the hearing, ${ }^{39}$ and any waiver of the hearing would need careful regulation..$^{40}$ Assuming that such a procedure could be successfully implemented, this interpretation would be clearly more consistent with the Court's substantive focus on procedural control of creditor behavior. It would require, however, constitutional regulation of the consensual relationship between private parties.

In view of the difficulties inherent in incorporating the new requirements into a statutory scheme, post-Sniadach debate centered upon the appropriate circumstances under which the additional procedures would not be required. In Sniadach, the Court indicated that traditional requirements of due process would still govern in cases involving extraordinary state or creditor interests where the statute was narrowly drafted to apply only to such special situations. ${ }^{41}$ Since provisional remedies are generally used only when the creditor fears loss or destruction of security or the dissipation of assets prior to judicial resolution of the claim, due process might then be satisfied merely by redrafting statutes to so confine the use of these remedies without attempting to incorporate generally prior

${ }_{33}$ There are indications that a substantial minority of dehtors either do not receive notice of judicial action or fail to understand its meaning. Professor Caplovitz has found that $46 \%$ of debtors surveyed in New York claimed they were never served with process. 2 D. CAPLOVITz, supra note 30 , at 11-7. In addition, of those who were in fact served with process, $15 \%$ failed to answer the summons because they were unaware that they were supposed to appear in court, that is, "they did not understand the meaning of the summons." Id. at 11-38.

${ }^{30}$ Attempts to compel appearance through the contempt process would appear merely to add to the debtor's burden. See generally Alderman, Imprisonment for Debt: Default Judgments, the Contempt Power, and the Effectiveness of Notice Provisions in the State of New York, 24 Syracuse L. Rev. 1217 (1973). Additionally, perhaps debtors ought to he permitted to purchase a default at the least possible expense should they decide to do so.

to Specific formalities designed to establish an intelligent waiver have been adopted in criminal waiver cases. Miranda v. Arizona, 384 U.S. 436 (1966). The criminal waiver experience, however, tends to demonstrate that these requirements are largely ritualized formalities which ultimately fail to accoinplish their intended purposes.

" 395 U.S. at 339. 
notice requirements. The issue as framed for subsequent consideration by the Court posed a choice between a broad incorporation of prior notice and hearing requirements ${ }^{42}$ and a narrow limitation of those requirements to special types of property deserving extraordinary protection. ${ }^{43}$

\section{B. Fuentes v. Shevin: The High Water Mark of Procedural Due Process}

The question of procedural due process requirements and provisional creditor remedies reappeared before the Court in Fuentes $v$. Shevin, ${ }^{4}$ in an attack on Florida and Pennsylvania pre-judgment replevin procedures. ${ }^{45}$ Under the statutory scheme in both states, any creditor who filed an ex parte allegation that his "goods or chattels are wrongfully detained by any other person or officer" could have a writ of replevin issued directing the sheriff to seize the disputed goods. ${ }^{47}$ There was no statutory provision for notice to the debtor or for a pre-seizure hearing to determine the validity of the underlying claim. ${ }^{48}$

The Court, in finding this statutory scheme constitutionally defective under Sniadach, responded primarily to the issues as they had been framed in the interim. First, Mr. Justice Stewart, writing for the majority, explicitly articulated what had been only implicit in Sniadach-that procedural due process required notice and an opportunity to be heard prior to the deprivation; 49 a subsequent judicial determination that reversed the mitial taking could not constitutionally repair the initial wrongful deprivation. ${ }^{50}$ Secondly,

12 Deprivation of property rights is here defined along the lines of Mr. Justice Harlan's concurring opinion in Sniadach as incorporating the temporary deprivation of the use of property. 395 U.S. at 342 (Harlan, J., concurring). See cases cited in note 35 supra.

13 See cases cited in note 36 supra.

" 407 U.S. 67 (1972).

45 Fuentes involved the Florida replevin statutes; its companion case, Parhain v. Cortese, 407 U.S. 67, 70-71 (1972), challenged the Pennsylvania pre-judgment replevin process.

16 Fla. Stat. Ann. § 78.01 (1964).

"Id.

13 In Fuentes, the plaimtiff purchased consumer goods from the creditor under an installment sales agreement that granted the seller the right of repossession "in the event of default of any payment. . . ."A dispute subsequently arose over the servicing of the purchased goods and the dehtor stopped payment. In conforinance with the Florida statute, the creditor obtained a writ of replevin ordering the seizure of the goods by the sheriff pending a final judgment in the underlying action. 407 U.S. at 70-71.

4I Id. at 80.

so Id. at 82. Although Justice Stewart asserted that the right to a prior hearing was "no 
the Court rejected the argument that Sniadach protected only special types of "essential" property imterests." Seizing primarily on Justice Harlan's concurring opinion in Sniadach, Justice Stewart defined the deprivation that would trigger pre-seizure procedures as encompassing any temporary deprivation of the use of property pending final resolution of the underlying claim. ${ }^{52}$ Thirdly, the Court delimited those circumstances in which the pre-seizure requirements of due process would not be applicable. A justifiable ex parte seizure could occur only where the state could establish an important governmental or general public interest, ${ }^{53}$ where the stat-

new principle of constitutional law," the cases cited to support this proposition involved deprivations other than the exercise of provisional creditor remedies upon default. See, e.g., Bell v. Burson, 402 U.S. 535 (1971) (suspension of driver's license); Goldberg v. Kelly, 397 U.S. 254 (1970) (termination of welfare benefits). The right to a pre-seizure hearing in other contexts was not, in fact, a new constitutional concept, but im the default context it was unknown hefore Sniadach.

${ }^{31} 407$ U.S. at 88-90. Justice Stewart rejected the argument that Sniadach represented an attempt "to carve out a rule of 'necessity' for the sort of non-final deprivations of property that [was] involved." Id. at 89.

52 "The Fourteenth Amendment's protection of 'property,' however, has never been interpreted to safeguard only the rights of undisputed ownership. Rather, it has been read hroadly to extend protection to 'any significant property interest.'" Id. at 86.

53 Illustrations of special governmental interests cited by the Court included summary seizure under the internal revenue statutes, Phillips v. Comm'r, 283 U.S. 589 (1931); under a national emergency in times of war, United States v. Pfitsch, 256 U.S. 547 (1921); under an economic disaster due to bank failure, Fahey v. Mallonee, 332 U.S. 245, 247 (1947); see also Coffin Bros. Co. v. Bennett, 277 U.S. 29 (1928); and in order to protect the public against misbranded and contaminated foods and drugs, Ewing v. Mytinger \& Casselberry, Inc. 339 U.S. 594 (1950). 407 U.S. at 91-92. Based on this standard the replevin statutes in question were perceived as refiecting no more than "private gain." Id.

The Court did recognize several situations in which summary seizure would be permissible even though only the creditor's interest im collecting the obligation was involved. The first situation was limited to cases where there was immediate danger of destruction of assets. See note 54 infra. Secondly, the Court recognized the exception, noted in Sniadach, permitting summary seizure to acquire jurisdiction over a non-resident debtor. See note 27 supra. The Court indicated, however, that such use of summary process was limited to cases where prejudgment process was "necessary" to secure jurisdiction in state court, citing Ownhey v. Morgan, 256 U.S. 94 (1921). 407 U.S. at 91 n.23.

Several courts following Fuentes have continued to rely on the Court's reference to Ownbey in sustaining any pre-judgment seizure of a non-resident debtor to gain quasi-in-rem jurisdiction. See, e.g., U.S. Industries, Inc. v. Gregg, 348 F. Supp. 1004, 1021 (D. Del. 1972); Gordon v. Michel, 297 A.2d 420, 423 (Del. Ch. 1972). It has been argued, however, that a fair reading of Fuentes calls for a limitation on the use of summary attachment of a non-resident debtor to cases where the seizure was "directly necessary" to secure jurisdiction, and where alternative means of acquiring jurisdiction were not available. See generally Folk \& Moyer, Sequestration in Delaware: A Constitutional Analysis, 73 CoLuM. L. REv. 749, $762-77$ (1973). At least one court has followed this approach, finding summary seizure unconstitutional where quasi-in-rein jurisdiction was not necessary to perfect the jurisdiction of the state court. Welsh v. Kinchla, 386 F. Supp. 913 (1975). 
ute was narrowly drawn to protect that interest, ${ }^{54}$ and where the exercise of that interest by ex parte seizure was supervised by an appropriate "state official." "55 Finally, the Court addressed the question of waiver of these due process requirements. The Court perceived the consumer debtor-creditor relationship to involve a fundamental inequality of bargaining power; in Fuentes, this inequality was exemplified by an adhesion contract with fine print authorization of repossession upon default. ${ }^{56}$ Illuminating the substantive issue lurking in Sniadach, the Court emphasized that any waiver of predeprivation procedures must be knowingly and intelligently made. This debtor's status was to be distinguished from that of the debtor in D.H. Overmyer Co. v. Frick Co. ${ }^{57}$ in which the Court had held that a bargained-for confession of judgment clause in a commercial context was not per se violative of procedural due process.

The decision in Fuentes arose out of the same consumer debtor context as did Sniadach, and refiected the same inclinations to

34 The Court emphasized that statutes permitting ex parte seizure must be limited to special situations demanding prompt action. In the case of replevin this would include only situations in which the creditor could demonstrate an immediate danger that the goods would be destroyed or concealed by the debtor. 407 U.S. at 93 .

${ }^{55}$ The "state official" would be required to participate in the decision to seek a writ, to review the basis of the underlying claim, and to evaluate the necessity for seizure. Id.

${ }^{36}$ Id. at 94-96.

57405 U.S. 174 (1972). Overmyer is the clearest articulation of the substantive implications underlying the imposition of additional due process limitations on provisional creditor remedies. The warrant of attorney clause was executed by the debtor in return for an agreement by the creditor, inter alia, to extend the date of payment under the original indebtedness, to reduce the interest rate, and to release various mechanics liens. In rejecting the debtor's due process claim, the Court unanimously held that the record demonstrated a voluntary, intelligent and knowing waiver of "the rights it otherwise possessed to prejudgment notice and hearing. . . ."Id. at 187. In emphasizing the participation of legal counsel and the consideration received in exchange for the waiver, Justice Blackmun indicated that:

Our holding of course, is not controlling precedent for other facts of other cases. For example . . . where there is a great disparity of bargaining power, and where the Id. at 188 . debtor receives nothing for the cognovit provision, other legal consequences may ensue.

This explicit concern for the consumer debtor who is in an inferior market position subject to overreaching by creditors was reiterated by Justice Blackınun in Swarb v. Lennox, 405 U.S. 191 (1972), a companion case to Overmyer. In strongly-worded dicta he cautioned that:

In our second concluding comment in Overmyer, we state that the decision is "not controlling precedent for other facts of other cases," and we refer to contracts of adhesion, to bargaining power disparity, and te the absence of anything received in return for a cognovit provision. When factors of this kind are present, we indicate, "other legal consequences inay ensue." That caveat has possible pertimency for participants in the Pennsylvaniz system.

405 U.S. at 201. 
extend constitutional protections to the defaulting consumer because of his vulnerable status and inferior market position..$^{58}$ But now the argument assumed that the pre-seizure requirements could be incorporated into a statutory scheme of creditor remedies. Consequently, Fuentes contained the first glimmer of recognition that the implementation of these requirements would require a sig. nificant increase in the direct costs of the enforcement process. The Court responded directly to this issue by asserting that increased costs are not a sufficient justification for overriding a constitutional right, and that the onerous burden of such costs in the debtorcreditor context is not a basis for distinguishing this situation from others in which pre-deprivation protections are deemed essential..$^{59}$

The Court's unwillingness to balance the utility of preseizure hearmg requirements against increased litigation costs can be best explamed in terms of the underlying premise of both Sniadach and Fuentes. The primary concern was to regulate creditor behavior in a context where ordinary assumptions about the utility of the bargaining process were presumptively invalid; the imposition of preseizure procedural safegnards was assumed to establish a balance

ss This substantive concern with consumer debtors as a class is best reflected in Fuentes, where the Court, in denying that the statutory requirements of an imitiating bond by the creditor, allegations of entitlement, and possible damage liability are adequate protections agaimst error, states:

For if an applicant for the writ knows that he is dealing with an uneducated, uninformed consumer with little access to legal help and little familiarity with legal procedures, there may be a substantial possibility that a summary seizure of property-however unwarranted-may go unchallenged, and the applicant may feel that he can act with impunity.

407 U.S. 67,83 n.13 (1972).

${ }^{50} \mathrm{Id}$. at $92 \mathrm{n} .29$.

Justice Stewart in Fuentes remaimed singularly unimpressed with arguments directed to. ward the decreased "efficiency" of the additional procedural requirements:

Procedural due process is not intended to promote efficiency or accommodate all possible interests: it is intended to protect the particular interests of the person whose possessions are about to be taken.

Id. at $90 \mathrm{n} .22$.

Indeed, while the Court has recognized tbe possible relevancy of questions of "efficiency" in constitutional adjudication, it has empbasized that such values must give way to "bigher values." Stanley v. Illmois, 405 U.S. 645, 656 (1972).

It is submitted, however, that efficiency bas been given a pejorative connotation by the Court because the tern has been used only to signify a reduction in the direct costs of enforcement. If, however, the question is posed in terms of "economic efficiency," which calculates total enforcement costs as an attempt at value maximizing, the analysis should be relevant and entightening. 
in the debtor-creditor relationship absent due to market inequalities that precluded a fairly bargained-for agreement on default procedures. Uncertainty as to the full implications of this assumption perhaps best explains the Fuentes Court's failure to adopt the "compulsory hearing" imterpretation of the Sniadach requirements. Although much of the Fuentes opinion focused on the need for debtor participation in a hearing as the essential test of the validity of the deprivation, ${ }^{60}$ the Court indicated that the constitutional right was limited to "an opportunity to be heard."61 Then, implicitly recognizmg the potentially limited effect such a requirement could have in reducing the probability of error, the Court stated:

Since the issues and facts decisive of rights in repossession suits may very often he quite simple, there is a likelihood that many defendants would forgo their opportunity sensing the futility of the exercise in the particular case. And, of course, no hearing need be held unless the defendant, having received notice of the opportunity, takes advantage of it. ${ }^{.2}$

The significance of the probability that few debtors would exercise their right to a pre-seizure hearing opportunity was recognized by Mr. Justice White in his dissenting opinion in Fuentes. He asserted that although "[t]he Court's rhetoric is seductive ... in end analysis, the result it reaches will have little impact and represents no more than ideological tinkering with state law." ${ }^{33}$ Even if prior notice and hearing requirements were implemented as prescribed in Fuentes, the creditor "need only give a few days notice of a hearing, take possession if hearing is waived or if there is default; and if hearing is necessary merely establish probable cause for asserting that default has occurred."64 Based on this analysis, Justice White concluded that there was significant doubt that the pre-seizure requirements would meaningfully increase the protection provided to the debtor under present law. ${ }^{65}$

Although an evaluation of this perception requires a more precise analysis of the enforcement costs of these standards, the debate over costs was a significant recognition of their relevance to a determina-

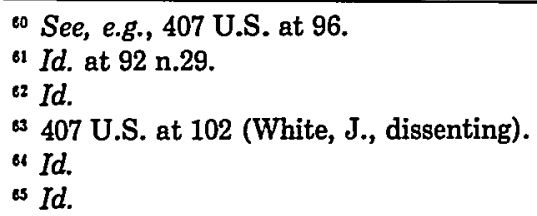


tion of the appropriate extent of constitutional regulation. The issue remained unresolved, however, and the legislative response to Fuentes centered primarily on the effort to redraft statutes governing ex parte creditor remedies to fit within the narrow exemption recognized by the Court. ${ }^{66}$

\section{Mitchell v. W.T. Grant Co.: A Retreat from Fuentes?}

This legislative response to Fuentes was, perhaps, predictable because of two factors: 1) the Court had left a narrow opening through which carefully drafted statutes might constitutionally pass; ${ }^{67}$ and 2) the absence of any accurate calculation of enforcement costs left most legislatures unsure of the economic effect of actually implementing the additional procedural requirements.

It was therefore inevitable that the issue would return to the Court framed in terms of the first factor..$^{68}$ In considering a challenge to the constitutionality of the Louisiana sequestration procedure, ${ }^{80}$ the Court elected to consider what kinds of statutes would be sufficiently circumscribed to permit ex parte process. In Mitchell $v$. $W . T$. Grant $\mathrm{Co}^{70}$ the creditor, alleging default on a credit sale of consumer goods in which he claimed a vendor's lien, filed an ex parte petition for a writ of sequestration. ${ }^{71}$ Without notice to the

es See, e.g., the Virginia Detinue Statute, VA. Code ANn. $\$ \S 8-586$ to -593 (1974 Cum. Supp.). Following an opinion by the Virginia Attorney General that Virginia's statutory repossession procedure was unconstitutional in light of Fuentes, the Virginia legislature amended the statute hy: 1) requiring the ex parte process to be preceded by an application by the creditor presented to a judicial officer and by the presentation of evidence of the kind and value of the property; that the property would be sold, secreted, or materially damaged or destroyed; and that the creditor's claim of settlement had a substantial basis; and 2) specifically providing for a prompt post-seizure hearing either within 21 days of the issuance of process or earher, upon application of either party. Id. at $\S \S 8-586 ; 8-591$.

These changes were obviously designed to bring the statute within the exceptions to the Fuentes pre-seizure requirements by narrowing its applicability to cases involving a special creditor interest $\mathrm{m}$ prompt action, by requiring review, of the application by a judicial officer instead of the court clerk, and by creating a statutorily explicit access to a prompt postseizure hearing.

${ }^{67}$ Fuentes v. Shevin, 407 U.S. 67, 90-92 (1972).

es See, e.g., Turner v. Colonial Fin. Corp., 467 F.2d 202 (5th Cir. 1972); Sena v. Montoya, 346 F. Supp. 5 (D.N.M. 1972); Dorsey v. Community Stores Corp., 346 F. Supp. 103 (E.D. Wis. 1972); Thorp Credit, Inc. v. Barr, 200 N.W.2d 535 (Iowa 1972) petition for cert. dismissed 410 U.S. 919 (1973); Inter City Motor Sales v. Szymanski, 42 Mich. App. 112, 201 N.W.2d 378 (1972); Montoya v. Blackhurst, 84 N.M. 91, 500 P.2d 176 (1972).

"O LA. Code Clv. Pro. art. 3501-3576 (1964).

70416 U.S. 600 (1974).

"Id. at 601-02. 
debtor or an opportunity for a prior hearing, the writ was issued by a parish judge $\mathrm{j}^{72}$ upon the creditor's stipulated bond $\mathrm{d}^{73}$ and an affidavit alleging default, the existence of the creditor's lien, and a belief that the debtor would "encumber, alienate or otherwise dispose of the merchandise ... during the pendency of these proceedings. . . ." 74 After the constable had seized the goods, ${ }^{75}$ the debtor filed a motion to dissolve the writ asserting, inter alia, that the failure of the Louisiana procedure to provide prior notice and hearing opportunities violated due process. ${ }^{76}$

In affirming the Louisiana Supreme Court decision sustaining the writ, ${ }^{77}$ the Court rejected the debtor's due process claim, holding that the Louisiana system, by minimizing the risk of error and limiting the sequestration process to a narrow range of special creditor interests, was constitutional even without a provision for pre-seizure participation by the debtor. ${ }^{78}$ The retreat from Fuentes was preceded by a rehabilitation of the traditional pre-Sniadach due process concept that "where only property rights are involved mere postponement of the judicial inquiry is not a denial of due process, if the opportunity given for ultimate judicial determination is adequate." Justice White, now writing for the majority, found in the Louisiana procedures sufficient bases for distinction from the Florida and Pennsylvania statutes held defective in Fuentes. It was determinative in his judgment that: 1) the Louisiana procedure limited the right to an ex parte seizure to situations in which the debtor had the power to conceal, dispose of, or destroy the property pending resolution of the dispute, thereby limiting the factual issues to those of default and the existence of the creditor's lien;80 2) the

72 The Louisiana Code provides generally that the court clerk may issue a writ of sequestration, but art. 281 limits the power to issue writs in Orleans Parish, where the issue arose, to a judge. LA. CoDE Crv. Pro. arts. 281-83 (1964).

${ }^{73}$ La. Code Crv. Pro. arts. 3501, 3574 (1964). The creditor was required to furnish double bond in the amount of $\$ 1,125$.

" LA. CODE Crv. Pro. art. 3571 (1964). The statute requires only an allegation that the debtor has the power to conceal, dispose or waste tbe property, etc.

${ }^{75}$ La. Code Civ. Pro. art. 3504 (1964).

${ }^{76}$ The trial court ruled that the provisional seizure was not a denial of due process and the debtor appealed to the Louisiana Supreme Court. 416 U.S. at 603.

7269 So. 2d 186 (1972), cert. granted, 411 U.S. 981 (1973).

78 416 U.S. at 618-19.

38416 U.S. at 611.

${ }^{\text {so }} \mathrm{Id}$. at 614. In his dissent Justice Stewart disputed the existence of this distinction. In both cases he contended that the factual issues were the same: default by the debtor and the existence of the creditor's security interest in the property. 416 U.S. at 633. 
writ of sequestration could not issue upon conclusory allegations of entitlement, but required additional factual allegations to support the grounds relied upon;81 3 ) the factual showing was made to a judicial officer, rather than a clerk, and the writ could issue only upon his authorization; ${ }^{82}$ and 4) the debtor was entitled under the statute to an immediate post-seizure hearing and could secure possession of the goods even prior to such adjudication by posting an appropriate bond. ${ }^{83}$ Considering these distinctions in light of the significant interests of both parties in the property in question ${ }^{84}$ and the mcreased risks to the creditor's interest where pre-seizure notification was provided to the debtor, ${ }^{85}$ the Court concluded that this statutory procedure "effects a constitutional accommodation of the conflicting interests of the parties." 86

Since Fuentes purported to limit ex parte seizure to circumstances involving an overriding governmental or general puhlic interest, Justice White's effort to distinguish Fuentes is not particularly

814 U.S. at 617-18. Article 3501 of the Louisiana Code provides that:

A writ of attachment or of sequestration shall issue only when the nature of the claim and the amount thereof, if any, and the grounds relied upon for the issuance of the writ clearly appear from specific facts shown by the petition verified hy ... the petitioner. . . .

LA. Code Crv. Pro. art. 3501 (1964).

Justice Stewart challenged the probative value of requiring additional information on a standardized form affidavit and contended that these pro forma allegations were insufficient substitutes for a pre-seizure adversary proceeding. 416 U.S. at 631-32 (Stewart, J., dissenting).

${ }^{82}$ Id. at 616. Justice Stewart argued that the participation of a judicial officer was conatitutionally irrelevant, simce the nature of the duty remained essentially the same whether performed hy a judge or a clerk. Id. at 632 (Stewart, J., dissenting).

83. Id. at 618. Article 3506 of the Louisiana Code permits the defendant by contradictory motion to obtain the dissolution of a writ of attachment.

4 Under Louisiana law the imstallment seller has a vendor's lien to secure the unpaid balance of the purchase price. The existence of the hen made the debtor's property interest subject to defeasance upon default, his interest being limited to the surplus remaining after a foreclosure and sale of the property. LA. Code Crv. Pro. art. 2373 (1964).

${ }^{83}$ Under Louisiana law the creditor's lien on the property expires if the buyer transfers possession. Thus, Justice White contended, pre-seizure notice creates additional risks that the property will be conveyed prior to sequestration to third parties whose interests will he superior to the lien. 416 U.S. at 608-09.

A more limited analogy can be found in other jurisdictions where the creditor takes a security interest in consumer goods under Article 9 of the Uniform Commercial Code. Under UCC $\S 9-307(2)$ this interest is inferior to that of good faith buyers of such goods from the debtor if their purchase is for personal use, unless the creditor files a financing statement with respect to the goods.

ss 416 U.S. at 607. 
persuasive. ${ }^{87}$ The opinion does, however, raise some of the previously neglected but important questions about the ultimate effect on the enforcement process of imposing additional procedural requirements. Although the factual context here was once more the consumer debtor-creditor relationship, the Court used the peculiar status of the debtor in Sniadach as a means of limiting the thrust of that decision. ${ }^{88}$ Sniadach was seen as representing a particular need to control the overreaching creditor where the summary remedy affected the most vulnerable aspect of the consumer debtor's market position-his dependency upon current earnings. ${ }^{89}$ The need to protect the debtor's status was not so great where the deprivation involved the assertion of a creditor's security interest and was accompanied by additional controls on the creditor's use of the remedy.90 The Court apparently assumed that in this latter situation creditor leverage was diminished. In addition, where Fuentes posed the constitutional issue in terms of the fact of deprivation, without regard to the specific remedy invoked by the creditor, Mitchell recognized a possible distinction between the provisional remedy of pre-judgment garnishment (or attachment) and that of statutory repossession ${ }^{91}$ based on the repossessing creditor's significant present interest in the property subject to seizure. Where the remedy sought is statutory replevin, the creditor's interest in the property decreases in value in the case of default and continued possession and use by the debtor..$^{92}$ Furthermore, pre-seizure notice makes possible a transfer by the debtor in advance of repossession that could

"Fuentes limited these exceptional circumstances to cases involving broad governmental interests as opposed to the "private gain" represented by the replevin statutes. See note 53 supra and accompanying text. The majority opinion im Mitchell generated heated controversy among various members of the Court. In the opinion of Justice Powell, concurring in Mitchell, "The Court's decision today withdraws significantly from the full reach of [Fuentes], and to this extent I think it is fair to say that the Fuentes opinion is overruled. Id. at 623 (Powell J., concurring). Justice Stewart, in dissent, was of the same opinion: "this case is constitutionally indistinguishable from Fuentes v. Shevin. . . ." Id. at 634. In strongly worded language, he expressed his concern that the Court in Mitchell was overruling an established decision that was barely two years old. The only change that he could perceive to explain the reversal was in the composition of the Court (Justices Powell and Rehnquist did not participate in the 4-3 decision in Fuentes). Id. at 635. See Blackmun, J., dissenting in North Georgia Finishing, Inc. v. Di-Chem, Inc., 419 U.S. 601, 614 (1975).

ss See generally 416 U.S. at 614 .

${ }^{89} \mathrm{Id}$.

${ }^{50}$ Id.

"Id. at 604-05, 615.

22 Id. at 604 . 
subordinate the creditor's security interest to the rights of the transferee or other creditors..$^{93}$ The implicit question is whether the creditor's right to pursue remedies upon default is made more costly by prior notice and hearing where he asserts an existing property interest than where he seeks to secure assets in which he has no prior interest. ${ }^{94}$

In Mitchell, the Court clearly began to come to terms with the total costs of enforcement generated by the constitutional adjustment of default procedures, and its significant retreat from the Fuentes standards can be explained most rationally in terms of an implicit recognition, based upon a rudimentary cost analysis, that the Fuentes doctrine would significantly increase enforcement costs. $^{95}$ The apparent conclusion was that the increased costs of preseizure proceedings, particularly where the creditor's security interest was imperiled, would produce only a minimal reduction in the cost of error. First, the probability of error was already low because the statutory procedure in Louisiana significantly limited, in the Court's judginent, the factual context of the dispute to the issues of default and the existence of the creditor's security interest in the property. ${ }^{96}$ The assumption was made, probably correctly, that an uncomplicated factual determination created a higher probability that the ex parte action by the creditor would ultimately be sustained, and consequently that a pre-seizure hearing would not result in a significant reduction in the incidence of error ${ }^{97}$ Secondly, the impact of error had been minimized by the statutory provision for an immediate post-seizure hearing upon the debtor's application, thereby reducing the cost of delay to the debtor..$^{98}$ Although Mitchell did not attempt to frame the cost calculation in precise terms, the Court clearly concluded that, under the Louisiana sequestration

33 Id. at 608-09.

"See notes 209-13 infra and accompanying text. One of the questions certified by the Supreme Court in granting review of Sugar v. Curtis Circulation Co., 383 F. Supp. 643 (S.D.N.Y. 1974), was whether an ex parte attachment statute satisfies due process "to extent it permits attachment of property in which plaintiff does not have a vendor's lien or similar statutory hen." Curtis Circulation Co. v Sugar, No. 74-859, 43 U.S.L.W. 3545, 3546 (April $15,1975)$.

${ }^{95} 416$ U.S. at $607-08$.

is Id. at 609-10. It should be noted that, as Justice Stewart indicates in dissent, this same limited factual context is a feature coininon to all ex parte repossession procedures. Id. at 633.

"7 See notes 124-33 infra and accoinpanying text.

os 416 U.S. at 610. 
procedure, the presumed increase in direct costs resulting from the imposition of broadly conceived pre-seizure procedures was not warranted by the perceived reduction in error.

Mitchell is important because it reflects a significant shift in the Court's perception of the objective of constitutional control. Both Sniadach and Fuentes represent an attempt to regulate creditor overreaching in realizing a "private gain" upon default. ${ }^{99}$ In this context the mandates of due process are determined by balancing the interests of a creditor in securing the debtor's property against the interest of a debtor in preventing unjustified deprivations of his property. Implicit is the recognition that since the debtor-creditor relationship is essentially consensual, effective regulation where the creditor has a dominant market position requires supervision of the bargaining process. In Mitchell, however, the object of constitutional regulation is no longer the overreaching creditor, but rather the state enforcement mechanism that provides a procedure for the resolution of debtor-creditor disputes. The determination of due process standards on this basis requires balancmg the debtor's interest against the interest of the state in providing an efficient mechanism for resolving disputes between private parties. This return to the pre-Sniadach view of due process-focusing on state procedures rather than creditor behavior-eliminates the necessity of a substantive regulation of the agreement between the parties.

Although returning to a more traditional formulation of the affected interests subject to constitutional regulation, Mitchell emphasizes, and thereby identifies as constitutionally relevant, speciflc provisions of the Louisiana procedure which are not common to all state procedures governing provisional creditor remedies. Simply stated, Mitchell permits ex parte seizure upon default if the statutory remedy requires: 1) participation by a judicial officer; 2) additional factual allegations of entitlement; and 3) opportunity for an immediate post-seizure hearing. As indicated by Justice Stewart's dissent, it can be argued that these provisions have no measurable impact in increasing the probability of a correct ex parte determination: ${ }^{100}$ even accepting the balance as the majority frames it, the question remains whether these requirements, when constitutionally imposed, promote more effectively the assumed fundamental goals of legal procedure. ${ }^{101}$

\footnotetext{
Fuentes v. Shevin, 407 U.S. at 92.

100416 U.S. at 631-34 (Stewart, J., dissenting).

${ }^{301}$ See notes 197-206 infra and accompanying text.
} 
The Mitchell response to this question was ohscured by the Court's failure to articulate more precisely the constitutional standard that had emerged. Was the Sniadach-Fuentes broad standard of pre-seizure notice and hearing destined for an early grave? Surprisingly, as Justice Stewart was to remark, "the report of the demise of Fuentes $v$. Shevin . . . seems to have been greatly exaggerated." 102

\section{North Georgia Finishing, Inc. v. Di-Chem, Inc.: Fuentes and Mitchell Recycled}

Because Mitchell failed to distinguish Fuentes adequately or to overrule it expressly, it was followed by numerous challenges to other statutory provisional creditor remedies based upon alleged failures to provide the kinds of statutory protections deemed sufficient by the Court to justify an ex parte seizuure. ${ }^{103}$ It was barely eight months before the issue came to the Supreme Court once again for clarification. In a somewhat surprising opmion ${ }^{104}$ the Court in North Georgia Finishing, Inc. v. Di-Chem, Inc. held the Georgia pre-judgment garnishment statute unconstitutional as a violation of procedural due process. ${ }^{105}$

In $D i$-Chem, the creditor filed suit against a commercial debtor alleging an indebtedness of $\$ 51,000$, and simultaneously filed an affidavit and bond for pre-judgment garnishment of the debtor's bank account. ${ }^{108}$ Based on the affidavit asserting the indebtedness and the creditor's "reason to apprehend the loss of said sum . . . unless garnishment process issues," the court clerk issued a summons in garnishment to the debtor's bank. ${ }^{107}$ The debtor responded by filing a forthcoming bond discharging the garnisbee and a motion

\footnotetext{
102 North Georgia Finishing, Inc. v. Di-Chein, Inc., 419 U.S. 601, 608 (1975) (Stewart, J., concurring).

${ }^{103}$ See, e.g., Sugar v. Curtis Circulation Co., 383 F. Supp. 643 (S.D.N.Y. 1974) (New York attachinent law permitting $e x$ parte seizure without adequate post-seizure hearing violates due process); Garcia v. Krausse, 380 F. Supp. 1254 (S.D. Tex. 1974) (Texas sequestration statute that provided neither prior notice and hearing nor judicial supervision and immediate post-seizure hearing violates due process); Roberts v. MacCaulay, $232 \mathrm{Ga} .660$, 208 S.E.2d 478 (1974) (state possessory warrant proceedings under statute compelling production of property without prior notice and opportunity to be heard violates due process).

104 The transformation of the 4-3 majority in Fuentes to a 5-4 minority in Mitchell had led to the assumption that the Court was willing to recognize significant limitations on the application of the pre-seizure notice and hearing standards of Fuentes.
}

105419 U.S. 601 (1975).

106 GA. CODE ANN. \$§ 46-01-102 (1974).

${ }_{107}$ GA. Code ANn. \& 46-102 (1974). 
to dismiss the garnishment and discharge the bond asserting, inter alia, that the statutory procedure violated due process. ${ }^{108}$

The Georgia Supreme Court incorrectly interpreted Sniadach as creating protection for wages as a special type of property and therefore judged it mapplicable to pre-judgment garnishment of other assets of a debtor. ${ }^{109}$ The Supreme Court reversed, reasserting that Fuentes made Sniadach applicable to a temporary deprivation of any significant property right. While the length and severity of the taking might bear on the nature of the hearing, these factors were not determinative of the right to the pre-seizure hearing itself. ${ }^{110}$ With the revival of Fuentes as a broad standard requiring preseizure notice and hearing opportunities, the Georgia garnishment statute failed its constitutional test. Nor could the statute be saved by Mitchell, which the $D i$-Chem Court seemed to view as an exception to the application of the Fuentes rules. Unlike the Louisiana procedure, the Georgia statutory scheme required neither judicial participation nor specific factual allegations of entitlement, nor a prompt post-seizure hearing.

The major contention of the creditor was based on the substantive issue underlying the previous cases, which was posed correctly and directly to the Court for the first time. ${ }^{111}$ Did not Sniadach, Fuentes, and Mitchell reflect a constitutional protection of the consumer debtor's status-not his property rights per se-in cases where unequal market positions permitted creditor overreaching? If so, the extraordinary pre-seizure protections should not apply to a transaction between commercial parties of equal bargaining power. Forced to confront the question, the Court apparently concluded that a substantive notion of "constitutional unconscionability" could not be supported. Although recognizing that distinctions based on the status of the debtor might well reduce the impact of error, the Court held that even in the absence of the consumer debtor status the impact of an erroneous taking was sufficiently great "that some

${ }^{103}$ The only statutory provision permitting dissolution of the garnishment before final adjudication required the defendant to file a bond, payable to the creditor, conditioned on the payment of any judgment rendered on the creditor's claim. GA. CoDE ANN. $\S 46-401$ (1974).

$109231 \mathrm{Ga} .260$, 201 S.E.2d 321 (1973).

110419 U.S. at 606.

III Id. at 607. "Respondent also argues tbat neither Fuentes nor Mitchell is appropriate here because those cases dealt with the application of due process protections to consumers who are victims of contracts of adhesion. . . ." Id. at 723 . 
procedures are necessary to guard against the risk of initial error."112

The immediate reaction to this latest foray into the state enforcement process is that Fuentes, used by the Court to rebut the contention that Sniadach applied only to a specialized property interest, is alive and well. That Fuentes lives is probably true, but its health is subject to serious doubt. As indicated by Justice Powell in his concurring opinion, $\mathrm{Di}$-Chem might be viewed as a retreat from Mitchell, which had rehabilitated the traditional view that an adequate post-seizure determination was the test of due process as applied to deprivations of property interests. ${ }^{113}$ But the Court has also abandoned the substantive thrust of Sniadach-that due process could provide constitutional control over the exercise of provisional creditor remedies against a consumer debtor-abandonment related to the alteration in Mitchell of the equation of interests by which the requirements of due process are measured. Because the focus has shifted from the creditor's private interest to the interest of the state in resolving disputes between private parties, regulation of the consumer debtor-creditor relationship to prevent "unconscionable overreaching" is no longer as relevant to the constitutional question. Consequently, the Court apparently adopted in $D i$-Chem the proposition that due process limitations on creditor remedies, regardless of the context, embrace only procedural fairness. ${ }^{114}$ In so doing, it would seem logically to follow that the extent and specific nature of the procedures that are constitutionally imposed on the enforcement mechanism should bear some relationship to their effect in increasing the accuracy of the deprivation or in reducing the impact should error result. ${ }^{115}$

It can be assumed that the Fuentes standard is the consequence of the states' failure to circumscribe ex parte remedies sufficiently. The questions remain: What is required? When is it required? Are the requirements justifiable?

The only possible consistent reading of the cases requires a choice between: 1) pre-seizure notice and hearing opportunities based on Fuentes; or 2) ex parte process requiring participation by a judicial

112 Id. at 608.

"13 Id. at 609 (Powell, J., concurring). In Mitchell the Court revived the traditional notion that where property rights were concerned, procedural due process requirements were limited to an adequate hearing at some point in the process. 42 U.S.L.W. at 4675 , citing Phillips v. Commissioner, 283 U.S. 589, 596-97 (1931).

114419 U.S. at 608.

115 See notes 164-69 infra and accompanying text. 
officer, specific factual allegations of entitlement, and access to an "immediate" post-seizure hearing. This standard is apparently imposed on the exercise of any provisional creditor remedy. Although the Court in Mitchell recognized potential cost distinctions among the various remedies, the potentially lower direct costs of additional procedures in the garnishment setting was not a factor in invalidating the Georgia statute in $D i$-Chem. ${ }^{116}$ The question of justification remains, but the Court's apparent hesitancy to articulate clearly its procedural standards may reflect a growing awareness that, due to the complexity of the analysis, consitutionally imposed procedures may not be the appropriate vehicle for providing an efficient dispute resolution mechanism. ${ }^{117}$ The clearest call for a cost analysis of procedural due process comes from Justice Powell:

[T] he recent expansion of concepts of procedural due process requires a more careful assessment of the nature of the governmental function served by the challenged procedure and of the costs the procedure exacts of private interests. ${ }^{118}$

\section{E. Toward a More Rational Analysis of Procedural Due Process}

The path from Sniadach to Di-Chem is circular. The notion of substantive protection of consumer default that colored so much of the Sniadach redefinition of procedural due process appears largely to have disappeared. Gone with it is any serious thought that state enforcement procedures will be widely amended to implement the prior notice and hearing opportunities that Sniadach enunciated. ${ }^{110}$

116 The distinction between pre-judgment garnishment and pre-judgment replevin did not escape Mr. Justice Powell, who viewed the Fuentes standard as particularly inappropriate "in cases where the creditor's interest in the property may be as significant or even greater than that of the debtor." 419 U.S. at 609 (Powell, J., concurring).

11 See, e.g., the dissenting opinion of Justice Blackmun, 419 U.S. at 614; and the concurring opinion of Justice Powell, 419 U.S. at 609, 610-11.

118419 U.S. at 610.

"There have been some legislative efforts to incorporate pre-seizure requirements into pre-judgment remedy procedures. See, e.g., ConN. PuB. Act. No. 73-431 (1973). The Connecticut statute generally requires pre-seizure notice and hearing opportunities in all "consumer transactions" ( $\$ \S 2$ and 3 ). Section 5 permits ex parte seizure by court order in a consumer transaction upon the creditor's affidavit that the debtor is a non-resident, or that there is a reasonable likelihood that the debtor will remove himself or his property, or dispose or sequester his property. The debtor is given the right to challenge the order at a post-seizure hearing. Section 6 permits ex parte seizure without notice in a commercial transaction where the debtor has waived his rights under the act. 
This is not surprising, since it was implicit in Sniadach that such procedures were fundamentally inconsistent with the basic purpose of provisional creditor remedies. ${ }^{120}$ As a result, however, the range of permissible ex parte processes, which Sniadach and Fuentes conceived as a narrow class of exceptional cases, now appears to form the statutory universe against which the mandates of due process must be measured.

In terms of the balance between the competing interests of the debtor and the state enforcement mechanism, the Court has returned to the pre-Sniadach principle that the fundamental requirement of due process is an adequate opportunity for an adjudication of the underlying claim at an appropriate point in the enforcement process. ${ }^{121}$ The Court is now trying to refine the meaning of that traditional understanding: When must the hearing be held to be meaningful and "adequate"? What controls must be placed on the creditor's access to ex parte process? The Court has acknowledged that the resolution of these questions requires a precise balancing of the particular interests present in a given debtor-creditor dispute. ${ }^{122}$ Consequently, the requirements of due process may well vary depending on the existence of a number of variables which affect the cost-benefit calculation of a particular procedural standard.

The difficulty with precisely defining procedures to govern the exercise of provisional creditor remedies lies partly in the consensual nature of the transaction that produces the dispute-many of the variables affecting enforcement costs are either dependent upon the agreement between the parties or the relationship that produced the agreement. ${ }^{123}$ Accurate determination of the appropriate procedures requires a complex analysis based on reliable assumptions about the nature of the debtor-creditor relationship and the context of default, assumptions that may well be altered by the agreement and the bargaining process. But once the attempt to regulate the bargaining

\footnotetext{
120 See notes 36-37 supra and accompanying text.

121 North Georgia Finishing, Inc. v. Di-Chem, Inc., 419 U.S. 609, $609-10$ (1975) (Powell, J., concurring).

122 North Georgia Finishing, Inc. v. Di-Chem, Inc., 419 U.S. 611 (1975) (Powell, J., concurring); Arnett v. Kennedy, 416 U.S. 134, 155 (1974).

${ }^{123}$ Illustrations abound of the ways in which the agreement between the parties can alter the factual context of the dispute. For example, has the debtor agreed to permit the creditor to utikize ex parte process upon default? Has the creditor heen granted an interest in the debtor's property? Has the debtor agreed not to assert claims and defenses upon default?
} 
process is abandoned, the efficacy of defining additional constitutionally imposed procedures in order to reduce the total costs of enforcement is subject to considerable question. The decision in $D i$ Chem seems to recognize implicitly that the constitutional necessity for additional procedures should be determined only after a rational inquiry into the probability that the enforcement process will benefit by their inclusion. As a first step in that direction, the second part of this article proposes a model identifying the factors necessary to calculate the cost of procedural due process, and analyzes these Court-imposed procedures to determine whether, in fact, the enforcement process benefits from these additional procedures.

\section{The Cost of Procedural Due Process}

An efficiency analysis of procedural due process requirements presupposes the ability both to identify and to measure the social values represented by legal procedures. Assuming that a primary goal of procedure is to produce accurate dispute resolution, it is possible to pose the constitutional question in efficiency terms: Are the direct costs of the additional procedures greater than the resulting reduction in error costs? And if such an imbalance exists, should it influence the Court's determination of the procedures required by due process?

Arguably, however, legal procedures have intrinsic worth. ${ }^{124}$ Apart from reducing the risk of error, a trial-type adjudication may express social values such as fairness, dignity, and increased civility in the debtor-creditor relationship. ${ }^{125}$ Even though additional default procedures increase total enforceinent costs, they may reduce the social cost of default by providing an appearance of fairmess, even if a deprivation is ultimately sustained. It seems equally plausible, however, that additional procedures that do not reduce the cost of error will be perceived as costly formalities that merely increase the burden on the defaulting debtor. On this basis, additional procedures which are primarily cosmetic would diminish rather than enhance the desired social values.

These conflicting assumptions about the intrinsic worth of default

124 See generally Summers, A Critique of Professor Fried's Anatomy of Values, 56 CoRNeLL L. REv. 598, 620-23 (1971).

${ }^{125}$ Id. at 620-22. See generally Dauer \& Gilhool, The Economics of Constitutionalized Repossession: A Critique for Professor Johnson, and a Partial Reply, 47 S. CAL. L. Rev. 116, $147-49$ (1973). 
procedures cannot readily be empirically verified. The only remaining measure, therefore, of the value of procedural due process requirements is their impact on accurate dispute resolution.

\section{A. The Debtor-Creditor Relationship and the Context of Default}

In order to predict whether specific procedural requirements promote efficient dispute resolution, it is initially necessary to evaluate in the context of the dispute those factors that determine the costs of enforcement. It may also be socially important to attempt to determine how any additional costs will be distributed. The incidence of enforcement costs, however, is not strictly relevant to an efficiency analysis. ${ }^{126}$ The present inquiry is concerned with measuring the magnitude of the social costs of using particular enforcement techniques, not with where the costs will ultimately fall. In any event, absent more precise empirical information concerning the extent to which suppliers of credit can absorb or pass on increased costs, the incidence of enforcement costs upon default must be considered indeterminate. ${ }^{127}$ The following questions, however, are cru-

${ }^{125}$ There may be circumstances in which the incidence of enforcement costs will affect their measurement. For example, even assuming that costs are spread on a per contract basis, the impact of such costs may nonetheless fall most significantly on the high-risk debtor. To the extent that increased costs increase the total price of credit, on the margin it would appear to imcrease the incidence of default. At some point a marginal increase in enforcement costs will cause a marginal debtor to default because of inability to meet the increased price of credit. Where his default is not premised on a defense to the underlying obligation, the probabilities of error for him in the enforcement process will not have been significantly reduced by additional enforcement procedures.

${ }^{127}$ The principal systematic attempt to predict the incidence of increased enforcement costs in the context of default is Professor Johnson's study of automobile repossession in California. See generally Johnson, Denial of Self-Help Repossession: An Economic Analysis, 47 S. CAL. L. REv. 82, 107-13 (1973). Johnson, after assuming that the credit industry is not characterized by monopolistic profits, concludes that increased enforcement costs will fall primarily on low incoine, high risk consumers. His data supports a model in which most of the increased costs are neither absorbed by the suppliers of credit nor borne by defaulting debtors. Rather, the costs either are passed on by the creditor through increased finance rates or the creditor attempts to reduce litigation costs by increasing down-payments or undertaking more selective extensions of credit to eliminato potential defaulters. It is not clear, however, even assuming that increased costs are not absorbed in part by the creditor, that either of these responses will necessarily mean that the incidence of increased costs is regressive. See Dauer \& Gilhool, supra note 125, at 131-37. Professors Dauer and Gilhool challenge (1) the assumption that a significant proportion of increased costs will not be absorbed by the credit industry; and (2) the assumption that those costs that are passed on to credit users will not be equally distributed on a per contract basis to all credit users. Id. For Professor Johnson's reply to these criticisms, see Johnson, $A$ Response to Dauer and Gilhool: $A$ Defense of Self-Help Repossession, 47 S. CAL. L. REv. 151 (1973). 
cial to an evaluation of enforcement costs:

(1) To what extent do claims of default raise complex factual issues susceptible of accurate resolution?

(2) To what extent do informal controls reduce the probability of erroneous claims?

(3) To what extent do debtors with valid defenses oppose claims of default through the adjudicatory process?

Although empirical data on these questions are at best incomplete, some basic assumptions structure the context in which provisional creditor remedies are used.

\section{The Complexity of the Factual Questions Requiring Resolution}

An adjudicatory proceeding will more effectively reduce the risk of error where the factual issues are complex and are capable of accurate resolution. ${ }^{128}$ Both pre-judgment attachment (or garnish-

Whether those costs not absorbed by the suppliers of credit are distributed equally on a per contract basis are borne primarily by debtors who default, or fall disproportionately on a class of marginal consumers, depends upon a number of factors imcluding: (1) the extent to which marginal consumers are less sensitive to increases in either the price of credit or the cash price of goods and services; (2) the ability of creditors to recoup additional costs by deficiency suits against defaulting debtors; and (3) the relationship between adjustinent in contract terms through increased down-payments and subsequent collection efforts. On the question of consumer sensitivity to price, see generally D. CAPLOVITZ, THE POOR PAY MORE: Consumer Practices of Low-income Famimiss, chs. 5-6 (Free Press ed. 1967); Federal Trade Commission, Economic Report on Installment Credit \& Retall Sales Practices of District of Columbia Retailers (1968); White \& Munger, Consumer Sensitivity to Interest Rates: An Empirical Study of New-Car Buyers and Auto Loans, 69 Mrch. L. REv. 1207 (1971). The question of cost recovery through deficiency suits is discussed in Johnson, Creditors' Remedies and Rate Ceilings, 26 PERs. Fin. L. Q. REP. 64 (1972); but see Shuchman, Profit on Default: An Archival Study of Automobile Repossession and Resale, 22 Stan. L. REv. 20, 42 (1969). Concerning the relationship between down-payments and the degree of collection difficulty, see G. Moore and P. Kunen, The Quality of Ccmsumer Installment Credit 82 (1967).

${ }^{123}$ It should be noted, however, that merely because the factual issues in a given dispute are complex and theoretically subject to accurate determinations, it does not necessarily follow that a trial-type adjudication is an efficient means of ensuring the accuracy of the resolution. See generally Mashaw, The Management Side of Due Process: Some Theoretical and Litigation Notes on the Assurance of Accuracy, Fairness, and Timeliness in the Adjudication of Social Welfare Claims, 59 CoRNeLL L. REv. 772 (1974), in which it is argued that the nature and method of operation of social welfare programs linit the presumed effectiveness of trial-type adjudication in assuring accurate resolution of social welfare claims. Id. at 81115. The only assumption made in this discussion is that an adjudicatory proceeding will have a greater impact in reducing erroneous claims where the dispute presents complex factual questions which are capable of accurate resolution than where the factual questions are straightforward or not susceptible of accurate determination. 
ment) and statutory replevin generally require that the creditor establish (1) the existence of the obligation, and (2) grounds for invoking the pre-judgment seizure. ${ }^{129}$ The factual inquiries will generally be limited to non-payment and perceived difficulty in satisfying the obligation. These limitations result primarily from the substantive contours of the debtor-creditor relationship.

Where the debtor's obligation is unsecured, the creditor will generally have required the execution of a negotiable promissory note. As the holder of a negotiable instrument, the creditor prima facie establishes the obligation merely by producing the instrument. ${ }^{130}$ The issue will then be limited to the question of payment on the note unless the debtor can establish a defense to the underlying obligation. ${ }^{131}$

Yet this opportunity to raise a defense may prove illusory. Where the obligation arises from a loan, underlying defenses will generally be limited to usury or the creditor's failure to comply with federal disclosure requirements. Neither usually justifies non-payment; thus the debtor's ability to assert these claims affirmatively may not prevent the deprivation. ${ }^{132}$ The creditor may be the purchaser of an

122 See, e.g., the Virginia pre-judgment attachment statute, VA. CODE ANN. $\$ \S 8-519$ to 8 . 577 (1974 Cum. Supp.), and the Virginia Detimue Statute, VA. CODE ANN. $\S \S 8.586$ to 8-595 (1974 Cum. Supp.).

Under $\$ 8-519$ the right to sue out an attachment is granted to any person with a claim to any debt in excess of $\$ 20.00$ who can allege one of the specified grounds for attachment as provided in $\$ 8-520$. In addition to non-residency, the grounds for attachment are limited to removal, conversion, disposal or concealment by the debtor of his property.

In the case of an action in detinue (the equivalent of statutory replevin) $\$ 8-586$ perinits an ex parte seizure of specific property of the debtor where the creditor can establish (1) that his claim of entitlement has a substantial basis and (2) that the property will be sold, removed, secreted, destroyed or damaged if possession is permitted to remain in the debtor.

130 Uniform Commercial Code $\S \S 3-301,3-307,3-802$.

13i UNiform Commercial Code $\S \S 3-306,3-307$.

${ }^{132}$ Only about $20 \%$ of the state statutes governing usury provide tbat the contract is void or perinit a set-off against principal for violations of the interest limitation. See, e.g., 1 P-H Consumer and Commercial Credit; Installment Sales ๆf 15,902-15,961. In most jurisdictions the penalty for usury is limited to forfeiture of interest due on the obligation, which will not in itself operate as a defense to non-payment.

Under the Federal Consumer Credit Protection Act, 15 U.S.C. $\S \S 1601-81$ (1970), the creditor is required to disclose the terms and conditions of tbe credit extension, including the rate of interest, at the time the obligation is incurred. Violations of the disclosure provisions merely grant to the debtor the right to recover affirmative damages against the creditor equal to twice the amount of the finance charge, not to exceed $\$ 1000$, together with costs and attorneys fees in a successful action. 15 U.S.C. $\S 1640$ (a) (1970). Furthermore, the creditor's liabihity is limited by provisions: 
obligation which arises from a sale or provision of services on credit. In this case he can frequently use either his status as a holder in due course of the instrument or a contractual waiver of defenses in order to insulate the obligation from the debtor's traditional contractual defenses. ${ }^{\text {133 }}$

Where a secured creditor seeks to replevy his security, similar substantive barriers will frequently preclude the debtor from raising additional factual issues to prevent the deprivation. Only after notifying the creditor may the debtor withhold payment based on a claimed creditor breach by deducting the claimed damage from the remaining obligation. ${ }^{134}$ In any event, the debtor will generally have relinquished his right of set-off by the terms of the sales contract.

Even though technical barriers may limit the factual issue to nonpayment, the debtor may still perceive that his defense is real, and, in terms of that perception, that the deprivation is unjustifiable. Legal procedures may be a means of reducing the social cost of the debtor's frustrated expectation of receiving just treatment. ${ }^{135}$ But where these frustrations exist and are a cost of the legal system, additional enforcement procedures will not significantly reduce

a) enabling the creditor to correct any errors in disclosure within 15 days after discovering a violation and prior to the institution by the debtor of any action under the liability section, $\S 1640(\mathrm{~b})$;

b) enabling the creditor to avoid liability if he can deinonstrate an unintentional violation resulting froin a bona fide error "notwithstanding the maintenance of procedures reasonably adapted to avoid any such error," $\$ 1640$ (c); and

c) providing a coinplete defense to inost creditors who are assignees of the original transaction where the debtor has signed at the tine of obligation a written acknowledgement of receipt of a valid disclosure statement, $\S 1641$.

133 UNIForm Commercial CODE $\$ \S 3-302,3-305$. In addition, the agreement creating the obligation in nost cases will contain a waiver of defenses clause in which the debtor agrees not to assert against his seller's assignee unost of the defenses that might be available on the underlying transaction. Subject to statutory or judicial limitation, such clauses are valid and enforceable under section $9-206$ of the UCC.

A number of jurisdictions have limited the availability of third party freedom from defenses in the case of a consumer obligation, either by denying to the assignee-holder the status of a holder in due course and prohibiting contractual waiver of defenses clauses, or by permitting freedom from defenses only after a period of time within which the debtor is given the opportunity to assert clains on the underlying obligation against the assignee. See generally 1 CCH POVERTY L. REP. I 3125.

is! UNIFORM COMmercial CODE § 2-717. Under UCC § 2-607(1), upon acceptance of the goods the buyer inust pay at the contract rate. He has the right, upon timely notice to the seller after the discovery of any breach ( $\S 2-607(3)$ ), to seek damages for the alleged breach from the seller under section 2-714. His right to set off dainages by deducting thein from the price remaining unpaid is subject, however, to the notification requirement of Section 2-717.

135 See notes 205-07 infra and accoinpanying text. 
them if substantive legal rules continue to bar perceived defenses.

The second factual issue that must be resolved to sustain a temporary deprivation is the validity of the creditor's fear that, upon ultimate adjudication, the debtor will not have assets available to satisfy the claim. ${ }^{136}$ Although statutory requirements vary, most provisional remedies require a reasonable belief by the creditor that the debtor's property will be transferred, destroyed, sequestered, or abused prior to resolution of the claim. ${ }^{137}$ The question of "insecurity," as opposed to the initial question of non-payment, might raise complex and varied factual issues. If a truly objective standard of insecurity were imposed, a fact-finding process would presumably increase the accuracy of the determination. But given the initial fact of non-payment, the msecurity issue becomes entwined with the creditor's subjective belief that grounds for insecurity exist. An adjudicatory proceeding in this context may expose additional "facts," but importance of the creditor's subjective insecurity insulates the question from "accurate" resolution.

The assumption will be made, therefore, that the factual questions generally raised upon default are either uncomplicated or not readily amenable to accurate resolution. ${ }^{138}$ This assumption, of course, excludes those cases where defenses by way of set-off or

${ }^{135}$ See note 129 supra.

137 See generally $1 \mathrm{CCH}$ Secured Trans., II 250.

${ }^{133}$ It should he recognized that the statutory grounds for pre-judgment seizure are not always limited to the questions of non-payment and insecurity. For example, the New York Attachment Statute, N.Y. Crv. Prac. $\$ 6201$ et seq. (1963), permits an ex parte seizure upon the plaintiff's allegation that the defendant has defrauded him:

"An order of attachment may be granted in any action . . . when:

5. the defendant, in an action upon a contract, express or implied, has been guilty of a fraud in contracting or incurring the liability. . . ." Id. § 6201(5),

In finding the New York statute defective under the Mitchell standard, the district court in Sugar v. Curtis Circulation Co, 383 F. Supp. 643 (S.D.N.Y. 1974), rev. granted, 43 U.S.L.W. 3545 (April 15, 1975), recognized a distinction between the grounds for seizure in Mitchell and those authorized under the New York statute. The Louisiana court granting sequestration in Mitchell was faced with the traditional, factually uncomplicated issues of non-payment and insecurity. In Sugar the issue hefore the state court considering the attachment order was whether the defendant had defrauded the plaintiff. The court emphasized that this issue, "which involve[d] determination of suhjective elements of motive and intent, [was] notably unsuitable to determination on documentary proof alone." $383 \mathrm{~F}$. Supp. at 649. It seems clear that the court was correct in recognizing that the probabilities of ex parte error would be greater where the attachment was authorized upon ex parte allegations of fraud in the underlying transaction than where the process was issued upon allegations of non-payment and insecurity. 
counterclaim may be properly invoked and for which an adjudication may provide a significantly more accurate resolution. It does, however, support the hypothesis that few ex parte deprivations will be erroneous.

\section{Informal Controls as Disincentives to Error.}

The probability of erroneous claims also depends on the extent to which market forces discourage the creditor from pursuing his claim through the enforcement process. Particularly relevant, in the presumed limited factual context of the dispute, are possible controls on creditor error in claiming non-payment. Empirical data, although incomplete, indicates that, because of the high direct costs associated with their use, creditors generally regard provisional remedies as the least efficient method of securing payment. ${ }^{139}$ Assuming that the creditor seeks payment of the obligation, after the initial default an efficient creditor will attempt to secure payment at minimum expense. Upon default he will seek to maximize expected cash flow by immediate contacts with the debtor to ascertain the causes of non-payment and to attempt a "work-out."140 Thus, the postdefault creditor will usually proceed through a series of extrajudicial collection attempts, contractual re-writes, consolidations and extensions. ${ }^{141}$ As the delinquency continues, these contacts become more insistent and personalized, ${ }^{142}$ reflecting the creditor's economic motivation to avoid the increased cost of judicial enforcement.

If a creditor fits this model, these economic considerations minimize the possibility of creditor or debtor error in establishing the fact of default. Accountimg errors, payments lost in the mails, misapplied payments, or debtor failure to pay owing to temporary factors (neglect, absence from home) should be resolved during the

${ }^{139}$ See generally Johnson, Denial of Self-Help Repossession: An Economic Analysis, $47 \mathrm{~S}$. CaL. L. Rev. 82, 85-88, 90-93 (1973).

uo Id. at $85-88$.

111 Id. at 87, 94. A 1971 survey by the Consumer Bankers Association indicated that prior to any repossession on delinquent accounts in automobile credit sales tbere were an average of: 1) 3.6 extensions or re-writes; 2) 10.3 delinquency notices; 3) 12.2 telepbone calls; 4) 7.9 personal contacts. Id. at 94 .

${ }^{142}$ See generally Leff, Injury, Ignorance and Spite-The Dynamics of Coercive Collection, 80 YaLE L. J. 1 (1970); Scott \& Strickland, Abusive Debt Collection-A Model Statute for Virginia, 15 WM. \& MARY L. Rev. 567 (1974). 
period of contact prior to any attempted deprivation. ${ }^{143}$

The creditor will balance the amount he must spend to generate income from the delinquent account against the probabilities of receiving payments from the debtor. Only when he identifies the debtor as a "can't pay," rather than a "won't pay," does the present value of extra-judicial collection efforts decrease. ${ }^{144}$ At some point delay so reduces the value of property subject to seizure that the creditor resorts to the enforcement process. ${ }^{145}$

There may be a number of circumstances in which the postdefault process of informal collection will not eliminate the possibility of an erroneous claim. The debtor may refuse to pay because of perceived defenses to the underlying obligation. The creditor may be willing to incur the additional expense of ex parte process with a given debtor in order to demonstrate to other debtors his willingness to enforce payment. ${ }^{146}$ Finally, some creditors might not fit the model: rather than anticipating payment as the end product of the exchange, they rely on default, ex parte seizure, and resale as a means of return on their investment. The abuses attributable to the overreaching creditor raise issues that the legal system should not overlook. To the extent, however, that aberrant creditor action can be identified as "unconscionable" overreaching, it is unlikely that" " these problems can be efficiently addressed through a manipulation of default procedure without any substantive control of the bargaining process-particularly where the manipulation occurs at the level of constitutional adjudication..$^{147}$

\section{The Usefulness of the Adjudicatory Process in Preventing Erro-} neous Claims of Default.

Despite the general limitation of ex parte inquiry to the questions of payment and msecurity, the debtor can prevent deprivation in some circumstances by establishing a claim or defense to the underlying obligation. It is important, therefore, to determine whether

113 2 D. Caplovitz, supra note 37, at 12-60 to 12-68. Professor Caplovitz identified nine primary reasons for default, only two of which involved creditor and debtor error in payment.

1' Johnson, supra note 139, at 93.

145 Id. at 90-93.

Hs 2 D. CAplovitz, supra note 37 , at $12-56$.

167 The impact of the overreaching creditor on enforcement costs will be considered below in connection with a relaxation of the basic assumptions on whicb the model is based. See notes 211-14 infra and accompanying text. 
debtors with valid defenses use the adjudicatory process. On the basis of existing empirical data, the incidence of contested claims of default appears remarkably low. ${ }^{148}$ In Professor Caplovitz' study of defaulting debtors in four cities, over ninety percent of the judicial actions were found to have terminated in default judgments against the debtor. ${ }^{149}$ Most contested claims terminated in settlements favorable to the creditor; in only three percent did the debtors prevail. ${ }^{150}$ This evidence does not, of course, necessarily indicate that the overwhelming majority of debtors have no valid defense to the creditor's claim. Uncontested claims may also result from the debtor's fear, mistrust, or ignorance of the judicial machinery invoked by the creditor. ${ }^{151}$ Professor Caplovitz suggests that the most prevalent reasons for default ${ }^{152}$ are creditor or debtor payment error and non-payment by the debtor for reasons which do not present a legally sufficient defense. ${ }^{153}$ Nonetheless, the evidence that allegations of fraud or other defenses are also primary reasons for default precludes the assumption that a claim for default which reaches the enforcement process will, if contested, necessarily be resolved in the creditor's favor. Consequently, the only assumption that can be made is that the incidence of uncontested claims is a product of three factors: (1) some debtors have no legally sufficient defense to non-payment and determine not to purchase the additional procedures available to contest the creditor's claim; (2) some debtors have a claim or defense but determme that their stakes in the case

118 2 D. Caplovitz, supra note 37, at 11-35, 11-66; National Commission on Consumer Finance, Press Release, May 5, 1972. Prof. Caplovitz found that over $90 \%$ of the claims in the cities studied were terminated by default judgments. The National Commission report hased on a survey of selected banks and finance companies found that "nearly $65 \%$ of all judgments obtained by banks and more than $47 \%$ obtained by finance companies were entered by default, when the defendant debtor failed to appear."

149 2 D. CAPLovitz, supra note 37, at 11-35, 11-66.

150 Id. at 11-67.

131 White, The Abolition of Self-Help Repossession: The Poor Pay Even More, 1973 W1s.

L. REv. 503, 528-29.

132 D. CAPLOVITZ, supra note 37 , at 11-36.

15s Id. The nine primary reasons for default identified by Caplovitz can be placed in 3 hasic categories:

(1) Debtor or Creditor Error (2) (Debtor leaves town; payment misunderstandings)

(2) Non-Payment-No Defense (6) (voluntary overextension; victim of own third party; involuntary over extension; debtor irresponsibility; loss of income; marital instability)

(3) Non-Payment-Defense (1) (Allegation of fraud).

Id. at 12-60 to $12-68$. 
multiplied by the probabilities of prevailing are less than their litigation costs in presenting the claim; and (3) some debtors have a claim or defense for which the stakes multiplied by the probabilities of prevailing are greater than their costs of litigation but, owing to imperfect information, cannot make the economically rational decision.

The risk of error upon ex parte seizure is significant in those disputes with a potentially broadened factual inquiry. However, the evidence of uncontested claims indicates that this risk will not be reduced merely by providing the debtor an opportunity to adjudicate the clain unless he is also provided with sufficient information to permit him to evaluate the alternatives rationally. Consequently, providing pre-seizure notice and hearing opportunities without additional expenditures to increase information will only reduce the cost of error for those apparently few debtors who have claims that they are prepared to assert if given the opportunity.

\section{Summary.}

The preceding discussion has identified the basis for the assumptions underlying a cost analysis of additional procedural due process requirements. The central assumptions are: (1) that the factual issues in an ex parte proceeding are generally limited and uncoinplicated; (2) that informal controls on creditor behavior provide significant disincentives to error in invoking provisional remedies; and (3) that since most claims for default are uncontested, additional procedural requirements without significant expenditures on information are not likely to forstall erroneous deprivations even when the debtor has a valid defense. The empirical evidence supporting these assumptions is, admittedly, incomplete and subject to varying interpretations. ${ }^{154}$ The cost analysis which follows will therefore relax these assumptions where they are subject to challenge in order to test the validity of the additional procedures in the widest possible context.

\section{B. The Impact of Procedural Variables on Enforcement Costs}

A cost analysis of the procedures for enforcing provisional creditor remedies relies on Professor Posner's classic formulation: The purpose of legal procedure is to minimize the sum of two types of

154 See, e.g., Dauer \& Gilhool, supra note 125, and Johnson (hoth articles), supra note 127. 
cost-(1) the direct costs of operating the dispute resolution machinery; and (2) the social costs produced by an erroneous resolution of a given dispute. ${ }^{155}$ When this analytical framework is applied to provisional creditor remedies, it is presumed that ultimately there will be a final adjudication of the creditor's claim. Obviously, if final adjudication mistakenly imposes liability by depriving a debtor of his property where he has not defaulted, or mistakenly fails to assess liability where there is a valid claim of default, the mechanism will be less efficient because of the social costs produced by the erroneous resolution. In the provisional remedy context, however, the error costs of final resolution are not relevant; the issue is whether pre-seizure hearing opportunities or other requirements minimize the error costs of an ex parte seizure.

Because of the less searching nature of an ex parte proceeding, the probability of error upon ex parte seizure ("ex parte error") will be greater than upon ultimate resolution of the claim. Minimizing this higher probability of error is a legitimate goal of the legal system. ${ }^{156}$ Since ex parte error is "biased," operating only to the disadvantage of the debtor, ${ }^{157}$ a reduction in the probability of error will benefit the debtor by reducing the cost of error to him. The cost of ex parte error, however, is the product of two factors: (1) the increase in the probability of error where the initial taking is not accompanied by a fact-finding adjudication, and (2) the impact of an erroneous deprivation measured from the issuance of ex parte process until the ultimate adjudication. Consequently, the cost of ex parte error increases as the impact of that error on the debtor increases with probability of error held constant. The market value of this impact, absent equitable considerations, ${ }^{158}$ is the sum of: (1) the cost of borrowing the ainount of money representing the value of the prop-

${ }_{135}$ Posner, supra note 13, at 400. The basis for Posner's assertion is that the judicial process is designed in part to apply existing substantive legal rules in the context of dispute resolution. The costs of this process are not limited to the direct costs of operating the machimery, but include as well the reduction in efficiency of a mistaken imposition of liability or a mistaken failure to impose liability. Since, as Posner indicates, efficiency is used in its economic connotation of maximizing value, any reduction in either direct costs or the costs of judicial error increases its value and therefore forms a legitimate and significant goal of the legal system. Id. at $400-01$.

${ }^{156}$ Id. at 401.

137 Posner identifies error as either "biased" or "unbaised." Unbiased error is any error likely to operate equally against either party. Biased error is more likely to operate against one party than the other. Id. at 406-07.

${ }_{15 s}$ See notes 213-14 infra and accompanying text. 
erty rights seized for the period of the ex parte deprivation, ${ }^{160}$ and (2) the costs of making alternative arrangements. ${ }^{100}$ The greater the costs of deprivation, the greater will be the debtor's incentive to spend money in the enforcement process to avoid them. This extra expenditure in turn will reduce the probability that an erroneous claim will be sustained. ${ }^{161}$ But when additional procedures to reduce error are imposed, they may significantly increase the direct costs of enforcement. These costs include the opportunity costs of the litigants, attorneys, witnesses, etc., and the maintenance costs of the system itself, including salaries of employees, judges' time, operational expenses, etc. ${ }^{162}$ It will not be efficient, therefore, to reduce the costs of ex parte error if the direct costs of operating the mechanism increase by a greater amount. ${ }^{103}$ It is, however, the belief that some expenditures on procedural machinery will be more than offset by reductions in error costs that provides the basic justification for a fact-finding adjudication at some point in the enforcement. The question remains whether, in view of its uncertain impact on total costs, efficiency is inaximized by providing this opportunity before the deprivation, immediately after the deprivation, or in the ordinary course of events when the underlying claim is litigated.

Within this analytical framework, it is possible to examine the extent to which the various procedures that the Court has identified as constitutionally relevant minimize the costs of enforcing creditor claims through provisional remedies. The analysis logically begins by examining the procedural requirements imposed by Sniadach and Fuentes-notice and hearing opportunities prior to any seizure.

\section{Pre-Seizure Notice to the Debtor.}

The Supreme Court has not indicated that pre-seizure notice to the debtor has constitutional significance, except as a necessary preliminary to pre-seizure adjudication. ${ }^{164}$ But when examined separately, prior notice would appear to reduce total enforcement costs

${ }^{150}$ This formulation does not include any idiosyncratic value attached to the property hy the debtor. This is not to suggest that such values do not exist, but rather reflects the traditional view of the legal system that where value cannot he measured in market terms it cannot be recovered.

${ }^{100}$ See notes 203-05 infra and accompanying text.

181 See generally Posner, supra note 13, at 404.

182 Id. at 401.

${ }^{163} \mathrm{Id}$.

184 See notes 26-31 and 44-49 supra and accompanying text. 
only to the extent that, by promoting dispute settlement, it reduces the direct costs of litigation by an amount greater than the cost of notice itself. Prior notice may better inform the debtor of the consequences of default, encouraging him to enter into settlement negotiations with the creditor. To the extent that notice produces an information exchange prior to seizure, it improves the parties' estimates of the outcome of the adjudication and therefore improves the chances for settlement. But the evidence of existing post-default opportunities for significant information exchange, ${ }^{165}$ together with the apparently minimal informational value of judicial notice for defaulting debtors, ${ }^{166}$ limit the benefit of pre-seizure notification as an independent means of promoting settlement.

Since notice ordinarily accompanies any ex parte seizure, the increase in direct costs generated by a prior notice requirement initially includes only the creditor's opportunity costs of an additional venture to the clerk's office and the cost of delay in seeking an ex parte seizure. ${ }^{167}$ But a prior notice requirement inay also significantly increase the probability that the debtor will injure, sequester, or dispose of his property prior to seizure. Assuming the grounds for seizure exist, the potential frustration of a "rightful" seizure will increase the creditor's costs of enforcing a valid claim. ${ }^{168}$ The requirement of prior notice, therefore, seems an inefficient method of reducing litigation costs by promoting pre-seizure settlement. It would appear that prior notice will minimize enforcement costs only to the extent that, when accompanied by a prior hearing opportunity, it decreases measurably the probability of error, or the impact of error on the debtor.

\section{Pre-Seizure Hearing Opportunities}

Before assessing the impact on enforcement costs of pre-seizure notice and hearing, it is necessary to address an ambiguity in Sniadach and Fuentes. ${ }^{169}$ The Court's emphasis on adjudication as

${ }^{105}$ See notes 139-46 supra and accompanying text.

1002 D. Caplovitz, supra note 37 , at $11-30$ to $11-47$.

107 Presumably, if the requirement were limited to prior notification, the delay until seizure would be minimized.

${ }^{188}$ See, e.g., Justice White's majority opinion in Mitchell:

The danger of destruction or alienation cannot be guarded against if notice and a hearing before seizure are supplied. The notice itself may furnish a warning to the debtor acting in bad faith.

416 U.S. at 609.

${ }^{100}$ See notes 37-41 supra and accompanying text. 
the primary means of reducing error raised the question of whether such an adjudication should be required in all cases. An essential hearing requirement would reduce ex parte error in all cases. Since most debtors presently do not contest claims for default, ${ }^{170}$ a system would have to be devised either to compel the debtor's presence at the hearing or to ensure that his decision to waive his right is truly informed. ${ }^{171}$ A compulsory hearing would significantly increase direct $\operatorname{costs}^{172}$ and in most cases, where the debtor has no defense to the default claim, the reduction in error probabilities would be minimal. If waiver were permissible, the reduction in the probability of error would be less because the waiver, even if voluntary, was based on incomplete information. The increased costs of a monitored system of information exchange before waiver (for example, the costs of debtor access to legal counsel, and communication of information to the debtor) would seem to far outweigh the reduction in error that the system would generate.

This imbalanced cost equation was not unforeseen by the Fuentes Court. That decision emphasized that the constitutional right was limited to the opportunity for a pre-seizure adjudication. ${ }^{173}$ But defining the requirement as the opportunity for a hearing rather than as a compulsory adjudication would seem to produce a smaller reduction in error probability. An adjudication before seizure would reduce the probability of biased ex parte error when the opportunity was exercised. But it would also introduce an additional random or unbiased error-the possibility that the hearing would fail to sustain a warranted deprivation as well as fail to protect against a wrongful deprivation. Because it is produced by a fact-finding process, unbiased pre-seizure error can be presumed to be smaller than the probability of ex parte error. Nevertheless, the calculation of the total enforcement costs of pre-seizure hearing opportunities must include the increased error costs of a wrongful failure to sustain deprivation.

Furthermore, it is not entirely clear that the exercise of a hearing

${ }^{170}$ See notes 148-53 supra and accompanying text.

in One attempt to work out a constitutionally valid system of post-default waiver of the rigbt to a pre-seizure hearing may be found in the Model Notice and Hearina for ProviSIONAL REMEDIES ACT $\S \S 4,5,7 \& 8$.

${ }^{172}$ Increased direct costs of a compulsory bearing would include additional litigants', lawyers', and witnesses' time, the creditor's costs of lost opportunity caused by delay in recovering tbe property, and the additional maintenance costs to the system caused by an additional litigation opportunity.

${ }^{173}$ See notes 60-62 supra and accompanying text. 
opportunity may not necessarily minimize the total costs of enforcement. To the extent that the creditor perceives pre-seizure unbiased error as significant, he will be encouraged to spend money in the litigation process to prevent it. A debtor who perceives a significant potential reduction in ex parte error will have a similar incentive to spend money. The increased investment of both parties in the factfinding process will reduce the probability of an erroneous adjudication. But expenditures in litigation do not unambiguously contribute to accuracy, and the increase in expenditures may, in some cases, exceed the reduction in error costs because each party's litigation expenditures are a function of his subjective probability of prevailing as well as his stakes in the case. ${ }^{174}$ From the perspective of the individual litigant, any expenditure is justified when the expenditure is less than his stakes multiplied by the percentage increase in his expectation of a successful outcome. In addition, each party's expenditures are in part a function of what the other party spends, and this interrelationship of expenditures may further reduce any direct relationship between expenditure and accuracy. ${ }^{175}$

Even assuming that pre-seizure adjudication can in theory produce a net gain, the analysis is altered significantly by the debtorcreditor relationship and the context of default. Where the factual questions are limited to payment and insecurity, pre-seizure adjudication will only slightly reduce the probability of error. ${ }^{176}$ Even where available defenses broaden the factual inquiry, a pre-seizure hearing option might not realize the potential reduction in ex parte error. Only a significant expenditure on information will permit the debtor to determine accurately the economic efficiency of using the hearing process. Without this expenditure adjudication will occur only in that very sinall percentage of cases in which the debtor has a defense and is prepared to assert it. When the right to a hearing

${ }^{17}$ See generally Posner, supra note 13, at 418-20, 429-35.

${ }^{173}$ Id. at $419-20,430-31$. Additional expenditures by one party will alter his subjective probability of prevailing, but it may also trigger increased expenditures by the other party, which in turn may offset the increase in the probability of prevailing. The extent to which expenditures on both sides cancel out and, therefore do not directly contribute to accuracy, must be regarded as indeterminate.

${ }^{178}$ In a limited factual environment, the only significant reduction in ex parte error would be the reduction in the probability of false claims of default. This would include creditor or debtor misunderstanding or negligence as well as willfully erroneous claims. The presumption is that the probability of "non-payment error" is small due to the existence of disencentives to error. See notes 139-45 supra and accompanying text. 
is not exercised, a pre-seizure hearing option will not significantly reduce the probability of ex parte error. The existence of the option will force the creditor to gather more information about the claimed default prior to instituting judicial enforcement, thus reducing the probability of a false claim of default even where no adjudication occurs. But assuming adequate informal controls on these false creditor claims, the reduction in error deriving solely from the existence of the option seems minimal. ${ }^{177}$ And since the debtor does not participate in the hearing, ex parte error caused by other factors, particularly failure to sustain legitimate debtor defenses, will remain unaffected. Consequently, the efficiency of the hearing option must depend on whether the assumed benefit in cases actually adjudicated is greater than the increase in direct costs in the great majority of cases where the option is not exercised.

The creditor cannot predict those situations in which a defaulting debtor will not seek a pre-seizure hearing. Consequently, the possibility of a pre-seizure hearing will require him, in the absence of waiver, to prepare a prima facie case upon every claim for default. He must incur opportunity costs, lawyers' and witnesses' time, even though in most cases these costs will not significantly reduce ex parte error because the seizure will be de facto ex parte where the debtor fails to appear. ${ }^{178}$ These additional costs can be reduced to some extent by permitting debtor waiver of the hearing opportunity. ${ }^{179}$ But waiver provisions decrease the benefit gained through a hearing requirement unless they are premised on a significant expenditure on information to the debtor so that his decision can be economically rational. This expenditure would be justified only if the evidence pointed to a high probability of error in ex parte seizure attributable to the large number of debtors with valid claims of which they were unaware. ${ }^{180}$ In the absence of expenditures to produce intelligent waiver, insuring voluntariness would require a post-

17 But see Dauer \& Gilhool, supra note 125, at 146-47. Dauer \& Gilhool argue that a requirement of pre-seizure notice and hearing would have a deterrent effect on creditors and serve to inhibit tortious creditor conduct. Id. Given the cost to the creditor of using the enforcement mechanism, while the opportunity for pre-seizure notice and hearing may operate to control extra-judicial collection efforts by the creditor, it would not seem to have a measurable impact in reducing erroneous or willful claims of default.

${ }^{178} \mathrm{~A}$ fact-finding process is effective in significantly reducing ex parte error primarily where the debtor raises perceived claims or defenses, since the creditor must allege non-payment and grounds for seizure in any case where he uses provisional remedies.

179 See MoDEL AcT, supra note 171 , at $\$ \S 4,5,7 \& 8$.

180 See generally, 2 D. CAPLovitz, supra note 37 , at $12-60$ to $12-68$. 
default assertion of waiver by the creditor and a judicial determination of its validity. ${ }^{181}$ A judicially-regulated waiver procedure would also generate direct costs to the creditor: He would have to establish a system of post-default contact and waiver, and, in addition, be capable of producing prima facie evidence of the voluntariness of the waiver. Additionally, a hearing either to review the seizure request or to evaluate a waiver claim would increase the maintenance costs of the judicial system itself.

The final cost to the creditor would be the delay imposed by a prior notice and hearing opportunity. ${ }^{182}$ In the case of the secured creditor, delay increases his costs by the depreciation of the property subject to the claim, ${ }^{183}$ and by the opportunity costs of lost use of the property for the period of delay. ${ }^{184}$ For the unsecured creditor seeking prejudgment attachment or garnishment, the costs of delay would not seem so onerous. Since the property seized cannot be used until final adjudication, his costs would be limited to the increased risk that the debtor's property will not be available upon adjudication, and to increased opportunity costs caused by delay until final adjudication.

The creditor's increased costs from delay cannot be measured accurately, however, without considering the possible impact of

181 See MoDer. ACT, supra note 171, Comment to Section 8. "[T] decisions of the United States Supreme Court have made it clear that these rights may be waived by a debtor where such waiver is voluntarily, intelligently and knowingly made. Obviously, a court must scrutinize the facts of each case to determine whether or not this standard has been met." Id.

182 An accurate estimate of the delay caused by pre-seizure notice and hearing depends to some extent on the nature of the procedures adopted pursuant to the constitutional mandate. Professor Johnson estimates the delay caused by the abolition of self-help repossession and the incorporation of pre-seizure hearing opportunities to be 30 days, Johnson, supra note 139 at 96-97, a figure which White finds "sound and probably conservative." White, supra note 151, at 518. Dauer and Gilhool, on the other hand, point to the fact that the Court in Fuentes recognized that expedited proceedings could well be valid in order to minimize costs and therefore they argue that the delay would be considerably less. Dauer \& Gilhool, supra note 127, at 123-24. Since the Supreme Court in Lindsey v. Normet, 405 U.S. 56 (1972), sustained Oregon's unlawful detainer statute, which provided for trial on limited facts within six days, expedited proceedings held sooner than the 30 day estinate would probably meet the Court's conception of the requirement of prior notice and hearing opportunities.

tas See Johnson, supra note 139, at 101-02. Based on an estimated 30 day delay, Johnson estimates the depreciation costs in the case of automobile repossessions to be $\$ 57$ for new cars and $\$ 36$ for used cars.

is Id. at 103-04. A 30 day delay produces under Johnson's analysis a lost opportunity of $\$ 19$ for new car repossessions and $\$ 8$ for used cars. 
delay on the probability of settlement. ${ }^{185}$ Since, absent seizure, the debtor retains his property free from the creditor's claim, preseizure delay reduces the creditor's stakes in the case. Thus delay, by reducing the value of seizure to the creditor, increases his incentive to settle the claim. An increased probability of settlement will clearly reduce costs by reducing litigation expenditures. Delay in seizure, however, will not necessarily increase the probabilities of settlement. Delay may, for example, increase uncertainty as to the outcome of the dispute, which may in turn increase the probabilities of litigation. ${ }^{186}$ Furthermore, the settlement rate is a function of factors other than the parties' stakes in the case, including their litigation costs and their subjective estimates of the outcome. ${ }^{187} \mathrm{~A}$ change in one of these factors produces an indeterminate change in the others, since the level of the parties' expenditures in the case are not predictable. ${ }^{188}$ Given the complex relationship between delay and enforcement costs, ${ }^{180}$ the effect of delay must be regarded as indeterminate.

The presumed cost reduction from a pre-seizure adjudication in a small percentage of default claims would appear to be outweighed by the apparent increase in enforcement costs in the vast majority of claims. The probable absence of the debtor results in a seizure without a measurable reduction in the probability of ex parte error, but with a measurable increase in the costs of using the enforcement process. In the absence of factual variables that alter the economic model-particularly the existence of a high-risk consumer debtor whose error costs are incalculable because the impact

18s See Dauer \& Gilhool, supra note 125 , at $144-45$. The authors also argue that pre-seizure requirements would promote settlement by conferring new "power" on the debtor, thereby promoting equality of bargaining between debtor and creditor and facilitating settlement. Id. at $145 \mathrm{n} .92$.

${ }_{188}$ Posner, supra note 13 , at $420-21$. The uncertain effect of delay in increasing the settlement rate seems particularly evident in the case of pre-seizure delay, because it is not apparent that the debtor's stakes in the case are reduced by delay.

187 Id. at $417-20$.

188 Id. at $419-20,421$. This requires the conclusion that the conditions for settlement are indeterminate, since both litigation costs and the subjective probability of prevailing are functions of the expenditure decisions of the parties.

${ }^{189}$ Increased settlement rates produced by pre-seizure delay may in turn increase enforcement costs either by increasing the costs of settlement relative to the costs of litigation because of the ahsence of the litigation information necessary to calculate settlement offers, or by increasing error costs owing to the reduced application of substantive legal rules to creditor-debtor disputes. Id. at $420-29$. 
of any error is so severe ${ }^{190}$-pre-seizure hearing requirements may well increase the total cost of using provisional creditor remedies. Whether or not such a statutory scheme would be a wise exercise of legislative discretion, such a system would appear less justifiable when constitutionally imposed. This would seem particularly true since resort to ex parte process is a function of the consensual relationship between the debtor and the creditor, and since the Court remains unwilling to confront directly the question of substantive regulation of the bargaining process.

The Fuentes requirements cannot be clearly justified in terms of their potential impact on enforcement costs. But under Mitchell and $D i$-Chem, due process takes on an alternative formulation. It requires, at a minimum, participation by a judicial officer in the ex parte process, specific allegations of entitlement by the creditor, and debtor access to an "immediate" post-seizure hearing. ${ }^{191}$

\section{Judicial Participation in the Ex Parte Order.}

Mitchell identified as constitutionally relevant the statutory requirement that ex parte process issue upon the order and approval of a judicial officer, rather than upon affidavit to a clerk. The Court apparently assumed that this judicial approval would reduce the probability of ex parte error. The validity of this assumption depends in part upon whether the issumg officer requires a pro forma showing or engages in an imdependent fact-finding process. ${ }^{192}$

In order to use a provisional remedy under most statutory procedures, the creditor must allege non-payment and grounds for seizure. ${ }^{193}$ If he is prepared to establish this prima facie entitlement by sworn affidavit, he would probably be equally prepared to do so before a judicial officer. Since, in the debtor's absence, the factual question will necessarily be limited to these issues, judicial participation will reduce the probability of error only by eliminating willfully or patently erroneous claims. Assuming that informal controls

${ }^{100}$ See notes 214-19 infra and accompanying text.

${ }^{101}$ Mitchell v. W. T. Grant Co., 416 U.S. 600, 605-07, 616 (1974).

${ }_{102}$ An additional factor which could potentially reduce the probability of error would be the psychological impact of dealing with a judge rather than a clerk. Presumably, the creditor would have additional incentives to guard against false clains.

${ }^{133}$ See note 129 supra and accompanying text.

${ }^{194}$ It is not contended that creditors do not undertake collection actions through madvertance or spite. The premise, rather, is that such actions generally take the form of informal, albeit coercive; collection efforts which are less costly than judicial enforcement. See generally Leff, supra note 142. 
curtail unjustified creditor claims caused by inadvertence or spite, ${ }^{194}$ the reduction in error produced by this process seems negligible. Alternatively, the judge could engage in a wide-ranging fact-finding process designed to elicit potential claims or defenses available to the absent debtor. But because these issues are peculiarly within the knowledge of the debtor, and because the factual context is generally limited to payment and insecurity, ${ }^{195}$ the costs generated by such an ex parte inquiry would seem greatly to exceed the reduced probability of error.

The additional direct costs of requiring judicial participation would vary depending upon the perceived role of the officer in the ex parte process. If the creditor need only make a prima facie showing of non-payment and grounds for deprivation, additional costs would be such direct costs to the creditor as lost opportunity, additional lawyers' time, and costs of producing records, plus the additional system maintenance costs of using judicial, rather than clerical, time in issuing the process. Should process issue only upon a wide-ranging attempt at fact finding, the litigation costs to the creditor and maintenance costs to the system would necessarily be larger. In either event, the costs of requiring judicial participation would seem to increase at a greater rate than any corresponding error reduction caused by the procedure, regardless of the extent and nature of the judicial role.

\section{Factual Allegations of Entitlement in the Ex Parte Affidavit.}

Mitchell also focused on the statutory requirement that the ex parte affidavit issue only upon the creditor's specific factual allegations of the grounds for seizure. ${ }^{196}$ Specific allegations of entitlement have no value in promoting information exchange between the parties, since they are not communicated to the debtor. Further, because the creditor has traditionally been required to allege entitlement by affidavit, this additional requirement will not reduce willfully erroneous claims. ${ }^{197}$ The benefit, if any, of specific factual allegations lies in reducing the incidence of negligent or unsubstantiated creditor claims of default. But existing disincentives seem to discourage inistaken claims of default more efficiently than would

${ }^{105}$ See notes 128-37 supra and accompanying text.

${ }^{186}$ Mitchell v. W. T. Grant Co., 416 U.S. 600, 605-07, 616 (1974).

${ }^{187}$ It would seem that a creditor willing to swear falsely in a conclusory allegation of entitlement will be equally prepared to undertake a more detailed allegation. 
pro forma allegations in a standardized affidavit. To the extent that this procedure becomes constitutionally necessary, it requires preparing forms with appropriate blanks for the creditor routinely to complete and slightly increases the costs to the creditor of preparation of the affidavit. But more significantly, it also requires redrafting of numerous statutory procedures to incorporate a formal requirement which does not appear to reduce the costs of ex parte error to the defaulting debtor. The reasoning that such a procedure protects a constitutional right recalls the great Dickensian parodies of official circumlocution, and is itself evidence of the validity of a cost analysis of procedural due process.

\section{The Opportunity for an "Immediate" Post-Seizure Hearing.}

The most significant procedural requirement isolated by Mitchell was the debtor's right to seek an "immediate" hearing and a dissolution of the vrit after seizure. The specific dimensions of this requirement are neither clearly articulated in Mitchell, nor clarified in $\mathrm{Di}$-Chem. At a minimum the debtor must have an opportunity to challenge the deprivation and the creditor must "demonstrate at least probable cause" for the seizure. ${ }^{198}$ The impact of such a provision on enforcement costs, however, depends largely on unarticulated assumptions about the nature of this hearing opportunity. ${ }^{199}$ Using the Louisiana statute sustained in Mitchell as a model, it is clear that a prompt post-seizure hearing opportunity is not an alter-

198 North Georgia Finishing, Inc. v. Di-Chem, Inc., 419 U.S. 601, 606-07 (1975); Mitchell v. W.T. Grant Co., 416 U.S. 600, 625 (1974) (Powell, J., concurring).

The Louisiana statute sustained in Mitchell provided that:

The defendant hy contradictory motion may obtain the dissolution of a writ of attachment or of sequestration, unless the plaintiff proves the grounds upon which the writ was issued.

La. Code Crv. Pro. Art. 3506 (1964).

190 At least one court has found that the requirement of an immediate post seizure hearing is not satisfied unless the statute 1) requires tbat at the post seizure hearing tbe grounds upon which tbe writ of seizure was issued are proven, and 2) imposes that burden of proof upon the creditor. Sugar v. Curtis Circulation Co., 383 F. Supp. 643, 648-49 (S.D.N.Y. 1974). Under the New York attachment statute invalidated in Sugar, the defendant had the right to request a post-seizure hearing by a motion to vacate the order of attachment. N.Y. CIV. PRAC. $\$ 6223$ (1963). The court would vacate the attachment if it found "that the attacbment is unnecessary to the security of the plaintiff. . . "383 F. Supp. at 649 . The district court determined that the New York courts interpreting this provision had universally held that the burden of proof was on the defendant to establish that the plaintiff could not succeed at trial. Id. On this hasis the district court held that this post seizure hearing opportunity did not meet tbe standards prescrihed in Mitchell. Id. at 648. 
native to final adjudication but an additional proceeding in which the creditor must establish a prima facie case. ${ }^{200}$ Presumably the debtor, if not otherwise limited by substantive legal barriers, could raise claims or defenses which, if colorable, would require the dissolution of the writ. ${ }^{201}$

An immediate hearing benefits the debtor by reducing the delay between ex parte deprivation and a fact-finding adjudication of the basis for seizure. A post-seizure hearing designed to establish prima facie entitlement will reduce the total cost of error to the extent that it reduces both the probability of ex parte error through a factfinding process and the impact of that error by decreasing the period of wrongful deprivation. A post-seizure hearing that is less than a complete fact-finding adjudication will reduce, but not eliminate, the probability of ex parte error. This reduction will be greater to the extent that the post-seizure hearing incorporates more of the features of an ultimate fact-finding adjudication. But a complete adjudication requires time for the parties to make litigation expenditures to establish the existence or non-existence of the claim. The more complete and accurate the post-seizure hearing, the longer will be the ex parte deprivation, and therefore the greater the impact of error on the debtor. Each marginal reduction in the incidence of error by reason of a more effective adjudication produces a corresponding marginal increase in the impact of error due to the delay necessary to permit that adjudication to be effective. Conversely, a inarginal reduction in the impact of error by requiring an "inmediate" hearing results in a marginal increase in the probability of an erroneous adjudication. In order to minimize the total cost of error it is necessary, therefore, to identify the point at which the probability of error is decreasing more rapidly than the impact of error is increasing. In the absence of the additional empirical data establishing this point of optimal efficiency, it is not at all clear that an immediate post-seizure hearing opportunity reduces error to a greater extent than a more complete adjudication later in the process. In addition, as in the case of a pre-seizure hearing, any reduction in ex parte error produced by an immediate post-seizure adjudi-

${ }^{200}$ See, e.g., LA. Code Civ. Pro. Arts. 3506, 3510 (1964).

201 Whether the debtor is permitted to raise defenses or claims by way of set-off is unclear under the Louisiana procedures sustained in Mitchell. Presumably the debtor should be permitted to do so to the extent tbat his claim raises doubts as to the creditor's likelihood of prevailing upon final adjudication. 
cation must be balanced against the additional unbiased error cost generated where the writ of seizure is erroneously dissolved.

Although an immediate post-seizure hearing would necessarily increase the direct costs of enforcement by providing an additional opportunity to litigate prior to final adjudication, the costs of this procedure should be lower than those generated by pre-seizure hearing requirements. Many of the litigation costs of pre-seizure adjudication will be eliminated, since the debtor initiates the hearing and the creditor need not incur additional costs when the hearing opportunity is not used. Since the seizure will have been effected, opportunity and other costs to the creditor imposed by pre-seizure delay will also be eliminated. The principal increase in direct costs will be limited to the litigation costs imposed on both parties when the right to a hearing is exercised and to system maintenance costs of providing an additional litigation opportunity. Presumably the debtor will incur these costs only when the perceived reduction in error costs through an effective adjudication is greater than his increased litigation costs.

A final consideration is whether an immediate post-seizure hearing, by reducing the delay until adjudication, will affect the probability of settlement. Since post-seizure delay increases the impact of deprivation, it decreases the value of litigation to the debtor. ${ }^{202}$ Post-seizure delay may also reduce the value of the seized assets to the creditor. But it can be assumed that the creditor's discount rate is lower than the debtor's, since the cost of borrowing money for the period of delay is generally greater for the debtor, particularly if he is an individual consumer. ${ }^{203}$ Additionally, the debtor's need for the seized property may be more acute than the opportunity costs of the creditor during the delay. Thus, post-seizure delay may increase the probability of settlement. Since delay has a more severe impact on the debtor's stakes in the case, his maximum settlement offer increases more rapidly than the creditor's minimum offer falls. But the settlement rate is a function of factors other than the parties' stakes in the case. To the extent, therefore, that delay also affects the level of expenditure on litigation and, in turn, the parties' estimates of the outcome, the impact of post-seizure delay on settlement cannot be precisely determined. ${ }^{204}$

${ }^{202}$ Posner, supra note 13 , at 418.

${ }^{203}$ Id. at 420 .

201 Id. See notes 186-89 supra. 
The uncertain effects of an immediate post-seizure hearing on direct costs as well as on error costs argue strongly against constitutional imposition of an immediate hearing in addition to the final adjudication of the claim. A post-seizure adjudication that maximizes the probability of a correct resolution of the claim while minimizing the impact of an initially erroneous ex parte seizure is probably more efficient in reducing enforcement costs. The argument that the constitutional right should be defined with sufficient flexibility to permit state legislatures to determine the point of optimal effciency seems particularly persuasive when consideration is given to the impact of additional procedural variables not yet isolated by the Court as being constitutionally significant.

\section{Alternative Procedural Requirements-Prompt Final Adjudica- tion and Creditor-Debtor Bonds.}

The additional costs of litigation imposed by the immediate postseizure hearing requirement, as well as the additional unbiased error costs generated by a prima facie hearing, ${ }^{205}$ can be eliminated by confining the enforcement process to a single post-seizure adjudication. The principal objection to restricting the debtor to a single opportunity to raise his claims and defenses is that delay significantly increases the impact of ex parte error on the debtor. This objection can be tempered if the constitutional right is defined as requiring a prompt final adjudication after ex parte seizure. A prompt adjudication would maximize efficiency if it were held at that point when the fact-finding process could be sufficiently complete and definitive to minimize both the risk of an erroneous flnal resolution and the impact of ex parte error on the debtor. This procedure would not affect the probability of ex parte error, but it would reduce error costs by minimizing the ordinary delay until final adjudication. Since the probability of ex parte error is low due to the limited factual context of the dispute and existing disincentives to erroneous claims, minimizing its impact would appear to be a more efficient means of reducing the costs of error to the debtor. Furthermore, the increase in the direct costs of resolving the dispute would be minimized as well. The only significant additional direct costs of a requirement of prompt final adjudication would be the additional maintenance costs to the system. These would be offset

${ }^{205}$ See notes 178-82 supra. 
in part by a decrease in those opportunity costs which may result from the creditor's inability to use the seized property before final adjudication.

A prompt final adjudication will inore efficiently reduce the cost of enforcement when combined with another procedural variable largely ignored by the Court-a mandatory creditor's bond upon application for an ex parte writ and an opportunity for the debtor to free his assets by posting a forthcoming bond. ${ }^{206} \mathrm{~A}$ requirement that the creditor file a bond saving the debtor harmless in the event of an erroneous claim increases the creditor's stakes in the litigation. If the resulting impact on the settlement rate can be assumed to be indeterminate, the principal increase in direct costs produced by this requirement is the cost of the bond. Total enforceinent costs would nevertheless appear to be minimized because the bond requirement, by increasing the creditor's expenditures should deprivation prove wrongful, will increase his incentive to avoid initial errors, thereby reducing the probability of ex parte error. The bond will also reduce the impact of error to the debtor by assuring him an eventual recapture of his discount rate for the period of deprivation. Additionally, the debtor's opportunity to recover the seized assets by filing a bond in return will reduce the impact of error on the debtor by perinitting him to translate the social costs of error into a discount ineasured by the cost of the bond.

The preceding analysis has indicated that, in terins of the economic model presented, the imposition of any one of the procedural variables deeined constitutionally essential by the Court inay well increase the total costs of the enforcement process. Alternative procedural requirements - a prompt final adjudication and appropriate bond provisions pending adjudication-would seem to provide a greater probability of minimizing the total costs of enforceinent. A more definitive statement of the cost of procedural due process would be unjustified. Additional empirical information is necessary before the exact costs of specific procedures can be measured. The consensual environment that generates procedural arrangements upon default further complicates any attempt to deterinine the relative efficiency of a given procedural standard. Consequently, a final question that inust be considered is whether the cost analysis is

${ }^{200}$ The only recognition of the possible significance of statutory bonding provisions has been by Justice Powell in his concurring opinion in Di-Chem, 419 U.S. at 612. 
altered by factual variables which affect the context in which provisional creditor remedies are used.

\section{Factual Variables Altering the Cost Analysis of Procedural Due Process}

This discussion has proceeded on certain assumptions about the debtor-creditor relationship and the exercise of provisional creditor remedies. The factual context may not be constant, however; at least three variables in the structure of a given debtor-creditor dispute may alter the analysis of enforcement costs.

\section{The Nature of the Creditor's Interest in the Property Subject to} Seizure.

The Court in Mitchell recognized a potential distinction between the principal creditor remedies used upon default. In the case of prejudgment attachment or garnishment, the creditor has no prior interest in the seized assets of the debtor and these assets will normally bear no relationship to the obligation underlying the claim of default. ${ }^{207}$ On the other hand, where the remedy invoked is statutory repossession, the secured creditor has a significant interest in the property subject to seizure, ${ }^{208}$ increasing his stakes in the litigation. Where the process incorporates either pre-seizure hearing opportunities or an immediate post-seizure adjudication, error costs are greater to this creditor than to a garnishing creditor because of the more severe impact of an erroneous denial of the right to repossess. Further, the secured creditor has greater direct costs generated by pre-seizure hearing opportunities. Delay in seizure diminishes his interest in the property, measured in terms of both lost opportunity and depreciation, ${ }^{209}$ at a rate greater than that of an unsecured creditor invoking garnishment or attachment, who would not have the right in any event to realize his claim from the seized assets until final adjudication.

On this basis, the potential increase in total enforcement costs resulting from any of the current procedural requirements would probably be smaller in the case of pre-judgment garnishment than where the remedy is statutory replevin. Whether the difference in

\footnotetext{
207 Id.

${ }^{200}$ See notes 91-94 supra and accompanying text.

200 See notes 182-84 supra and accompanying text.
} 
costs is sufficient to justify additional procedures in the one case but not the other is not entirely clear. ${ }^{210}$ That this distinction was not used by the Court in $\mathrm{Di}$-Chem as a factor in invalidating the Georgia pre-judgment garnishment statute ${ }^{211}$ indicates a current constitutional perception that the type of remedy invoked is not a useful distinction in the definition of the constitutional right. This perception is probably justifiable, since in both the garnishment and replevin contexts it seems that the procedures imposed by the Court do not efficiently enhance accurate dispute resolution.

\section{The Consumer Debtor Status.}

Protecting the consumer debtor from creditor overreaching was the substantive principle underlying Sniadach's initial redefinition of procedural due process. But $D i$-Chem explicitly rejected that principle as a basis for delimiting the perimeters of due process. Nonetheless, the presence of the consumer debtor affects the calculation of the costs of the procedures used to enforce default claims. Borrowing costs are clearly greater for the individual consumer debtor than for a commercial debtor; therefore the impact of any ex parte error is also greater. Furthermore, the potential of an adhesion contract and the possibility of creditor overreaching may increase the probability of ex parte error. The low probability of ex parte error was premised in part on the existence of inforinal controls which operate as disincentives to creditor error. ${ }^{212}$ The effectiveness of these controls depends upon rational creditor behavior in attempting to generate payment on the obligation while minimizing collection costs. If a creditor calculates his return in part upon an expectation of default and the use of default. remedies, then the probability of false claims, or claims in which the existence of default is subject to greater factual dispute, increases. ${ }^{213}$

${ }^{210}$ This issue will be presented to the Court once more when it reviews tbe constitutionality of the New York attachment statute in Curtis Circulation Co. v. Sugar, No. 74-859, 43 U.S.L.W. 3545 (April 15, 1975). The district court, in finding the New York statute defective under the Mitchell standard, considered tbe lack of any present property interest by the attaching creditor as a significant factor in tbe decision:

First, the plaintiff-creditor in Mitchell had by virtue of a vendor's lien an actual possessory interest in the attached property. . . . [ Inn the case at hand, Curtis has never had a legally cognizable, concurrent possessory interest in the property which it attached; it had only its claim of fraud against . . . Sugar. . . .

Sugar v. Curtis Circulation Co., 383 F. Supp. 643, 649 (S.D.N.Y. 1974).

211 See note 116 supra and accompanying text.

212 See notes 139-46 supra and accompanying text.

213 See note 146 supra. 
Consequently, some consumer debtors may imcur error costs from ex parte seizure that are greater than those on which the model is based.

Assuming that the direct costs of additional procedural requirements remain constant, this potential increase in error costs might justify imposing additional procedures. The problem remains, however, of identifying in advance those situations in which the status of the debtor increases the costs of error to him. It was perhaps the error of Sniadach and Fuentes to attempt to deal generically with a problem that is not generic to the defaulting consumer debtor. The possibility of excessive creditor leverage and the increased impact of erroneous deprivations in some circumstances does not justify the assumption that increased error costs will be present in all or even most cases involving the defaulting consumer. If the increase in error costs is attributable to a fundamental imbalance in the market which is wrongfully exploited by a creditor, substantive rules designed to prevent exploitation would seem to address the problem more directly and successfully. The Court's unwillingness in DiChem to use the debtor's status to limit the scope of procedural due process may be a rejection of the use of procedural standards to control the particular substantive problem of creditor overreaching.

The dilemina remains, however, that without any limitations based on substantive principles, additional procedural controls have much less value in reducing the cost of erroneous deprivations. If we conclude that the problem with constitutional protection of defaulting consumers generally is that the substantive standard is overly broad, then perhaps more effective regulation will result from further narrowing, rather than expanding, the scope of extraordinary procedural control. To this end, there is a final category of debtors, perhaps more easily identifiable, for whom the costs of error cannot be translated effectively into any economic model.

\section{Equity and "Brutal Need"-The Non-Economic Debtor.}

Any model based on economic efficiency presumes the ability to translate various social costs into price terms. In particular, in an attempt to calculate error costs the debtor is presumed capable of borrowing for the period of deprivation the amount of money equal to the value of the assets seized. This assumption is generally recog- 
nized in statutory schemes by debtor bonding provisions. The economic model, however, does not adequately address situations where human need is great and the collateral impact of deprivation is immeasurable, or where the debtor is incapable of entering the credit market regardless of the discount. In such cases either the impact of error is so large, and perhaps immeasurable, or creditor leverage so increases the possibility of false claims, that extraordinary procedures would seem justifiable even where they may increase total enforcement costs. Such exceptional circumstances, most clearly reflected in Goldberg $v$. Kelly $y^{214}$ and in the mitial thrust of Sniadach ${ }^{215}$ would have to be carefully identified by the.Court, and the nature of the procedures used to protect against ex parte error carefully delimited. Prior notice and hearing opportunities would not reduce error (assuming they did not prohibit de facto the use of provisional remedies) unless they were a realistic alternative for the non-economic debtor. If such a debtor is presumed to be a particularly vulnerable, high-risk consumer, then empirical data suggest that he will be relatively uneducated and uninformed concerning his legal rights, and psychologically averse to the legal system. ${ }^{218}$ Meaningful notice to the debtor would require an expenditure to increase the information available to him. If the hearing were not required, then access to the opportunity would also have to be adjusted to meet his peculiar needs. ${ }^{217}$

Assuming procedures adequate to reduce the costs of error in the context of "brutal need," the circumstances in which these unusual procedures should be invoked must also be expressly defined. Any attempt to distinguish on the basis of the consumer debtor status, without a concurrent monitoring of the bargaining process, is insuf-

214397 U.S. 254 (1970). In Goldberg, the Court held that an opportunity for a trial-type hearing must be afforded social welfare claimants before termination of public assistance henefits. The most significant factor underlying the decision apparently was the "brutal need" of any person wrongfully denied public assistance benefits. 397 U.S. at 264 .

${ }^{215} 395$ U.S. 337, 341-42 (1969).

${ }^{215}$ See generally $1 \mathrm{D}$. CAPLOVITz, supra note 37 , at 39-97.

${ }^{217}$ A strong analogy seems to exist between the "brutal need" debtor and the social welfare claimant faced with a denial or termination of assistance benefits. In both contexts translating procedural due process into a reality becomes a particular problem for the legal system. See generally Scott, The Reality of Procedural Due Process-A Study of the Implementation of Fair Hearing Requirements by the Welfare Caseworker, 13 WM. \& MARY L. REv. 725, 760-63 (1972). For a particularly thoughtful consideration of this problem, suggesting quality control and other management processes in order to assure the accuracy, faimess, and timeliness of the hearing process, see Mashaw, supra note 128. 
ficiently circumscribed to justify the extraordinary costs incurred. An alternative, as was suggested following Sniadach, ${ }^{218}$ would be to identify the procedural protections not with the debtor, but with the property rights subject to the seizure. To the extent that wage garnishment in particular encoinpases the problems caused by "brutal need," it is perhaps justifiable, in the absence of a more accurate means of identification, to limit these extraordinary protections to that particular remedy. ${ }^{219}$ The prohibitively high cost of this conception of procedural due process would most probably abolish prejudgment wage garnishment as an effective creditor remedy. The danger remains, however, whenever enforceinent procedures are used to control a particular substantive problem, that a generalized procedural structure will develop, increasing the cost of using the dispute resolution mechanism without a corresponding decrease in the costs of systemic errors.

\section{Conclusion}

The preceding analysis demonstrates the particular problems with a constitutional definition of the requirements of procedural fairness in the enforcement of creditor claims. At its genesis, Sniadach, responding to a "brutal need," attempted to control creditor overreaching in default arrangements with consumer debtors. Whether or not this concept of "constitutional unconscionability" was an appropriate constitutional principle, it justifies additional procedures as protecting social values that cannot be measured accurately by an efficiency analysis. In addition, Sniadach could perhaps be justified in cost terms had the extraordinary procedural requirements either been limited to the narrow factual context of the "brutal need" debtor or imposed in conjunction with an attempt to control creditor overreaching.

The Court's failure either to articulate a substantive principle or to limit the enlarged concept of due process produced in Fuentes an extension of this concept to the defaulting consumer debtor generally. Although Sniadach and Fuentes dealt with analogous remedies, such an extension in the scope of protection required a mark-

${ }_{213}$ Note, The Growth of Procedural Due Process Into a New Substance: An Expanding Protection for Personal Liberty and a "Specialized Type of Property". . . In Our Economic System," 66 Nw. U. L. Rev. 502 (1971).

210 "We deal here with wages-a specialized type of property presenting distinct problems in our economic system." Sniadach v. Family Fin. Corp., 395 U.S. 337, 340 (1969). 
edly distinct approach in order to ensure the utility of the procedural requirements. As the Court implicitly recognized, if the amount of procedural protection was to be based on contractual status, that status had to be protected by monitoring the bargaining process. The shift in Mitchell toward state enforcement procedures as the object of constitutional control represented a retreat from the consumer debtor focus. The Court effected this shift by undertaking an elementary cost analysis of the pre-seizure requirements as applied to a particular enforcement statute, and implicitly limited the justification for additional procedures to their benefit to the enforcement process generally. The decision, however, isolated as constitutionally relevant specific procedures that were not clearly justifiable in terms of the cost-benefit equation used to limit the effect of Fuentes.

The resolution in Di-Chem represented an explicit rejection of consumer debtor status as the line of demarcation for expanded due process. But the Court failed to identify any of the variables affecting the standards of due process, perhaps because of a growing awareness of the dilemma inherent in such a use of constitutional control. If the new standards are applied only to the defaulting consumer, then a significant reduction in error costs requires regulation of the contractual relationship. Alternatively, if the additional procedures are applied to all defaulting debtors, the benefits in increased accuracy and protection of the debtor's interest are significantly reduced; increased costs of the procedures may well offset thein. What may ultimately be emerging is a realization that the efficacy of specific default procedures can be more accurately determined by legislative, rather than constitutional, processes.

Di-Chem's ambiguous adherence to the alternative procedures of a pre-seizure hearing opportunity or an immediate post-seizure hearing with additional controls on the ex parte process should not obscure the Court's apparent return to a more traditional understanding of due process as applied to provisional creditor remedies. ${ }^{220}$ In restructuring the equation to balance the debtor's interest against that of the state, the basic constitutional principle that remains is the opportunity for an adequate adjudication at an appropriate point in the judicial process. Within this framework, the Court seems prepared to use a cost-benefit analysis to determine the

${ }^{200}$ Mitchell v. W. T. Grant Co., 416 U.S. 600, 611 (1974). 
specific procedures essential to any given dispute. Consequently, what process is "due" may well vary depending upon the nature of the affected interets and the impact of specific procedures on those interests. ${ }^{221}$ But this basis provides little justification for additional procedures of general application, whether derived from Fuentes or Mitchell, because they do not permit consideration of the variables that alter the equation in a particular dispute. Limiting the application of the procedures to a particular contractual status without a continuing exammation of the consensual relationslip and the resulting bargain seems an equally ineffective method of determining the appropriate standards of due process.

The opportunity exists, however, for the Court to release state enforcement mechanisms from the rigid confines of constitutionally imposed procedures of questionable utility. The constitutional principle can be implemented more flexibly, and perhaps more efficiently, by limiting the generalized procedural requirements to a prompt final adjudication coupled with appropriate bonding provisions for the period of deprivation. Within that framework, the Court might narrow the scope of extraordinary control to the particular problem of the brutal need debtor. It is clear that between the limited application of extraordinary procedures to brutal need debtors and a general requirement of prompt final adjudication, there may be circumstances where the error costs to a particular debtor could be significantly reduced by additional constitutional controls.

${ }^{221}$ See generally, Arnett v. Kennedy, 416 U.S. 134, 154-55, 167-71 (1974). Guzman v. Western State Bank, 43 U.S.L.W. 2398 (8th Cir. 1975) represents an attempt by a court following the balancing approach of Mitchell to determine the appropriate standards of due process by weighing the interests in a particular debtor-creditor dispute. In Guzman, the court held tbat a summary seizure under the North Dakota attachment statute of a mobile home used as a residence violated procedural due process. The court found that the North Dakota statute did not meet the Mitchell requirements in tbat: 1) the creditor's affidavit did not allege belief that the property would be concealed, disposed of, or destroyed; 2) there was no judicial supervision of tbe ex parte process; and 3) the debtor's access to a prompt postseizure hearing was conditional on his furnishing an adequate bond.

The court determined that statutory restrictions on a post-seizure hearing and the absence of judicial supervision created a likelihood of significant error costs when viewed in terms of the characteristics of the property in the case- a mobile home constituting the only residence of the debtor's family. The impact on tbe debtor and bis family of losing their only residence outweighed the increased costs to the creditor of prior notice and a hearing, particularly where the creditor had not alleged an emergency situation requiring summary process. Invoking the "brutal need" reference in Sniadach, the court recognized that this case presented more than mere inconvenience caused by the deprivation of some household items; rather, "tbe debtors were truly driven to the wall by the seizure of the mobile home." Id. 
But to isolate those disputes through constitutional adjustment of the enforcement process requires a continuous supervision of consensual relationships between private parties.

The undesirable implications of "constitutional unconscionability" leave few alternatives. The harmful social consequences of creditor overreaching cannot be effectively controlled by constitutional manipulation of the enforcement process without seriously jeopardizing the state's ability to accomplish efficient resolution of the entire range of debtor-creditor disputes. Ill-defined requirements burden the enforcement mechanism; they may well increase the total costs of enforcement. This is inconsistent with a fundamental goal of the legal system-the efficient resolution of disputes. 